Review

\title{
Front End Projects Benefits Realisation from a Requirements Management Perspective-A Systematic Literature Review
}

\author{
Joas Serugga $^{1, * \mathbb{D}}$, Mike Kagioglou ${ }^{2} \mathbb{D}$ and Patricia Tzortzopoulos ${ }^{1}$ (D) \\ 1 Art, Design and Architecture, University of Huddersfield, Huddersfield HD1 3DH, UK; \\ p.tzortzopoulos@hud.ac.uk \\ 2 School of Engineering, Western Sydney University, Perinth, Sydney, NSW 2751, Australia; \\ m.kagioglou@westernsydney.edu.au \\ * Correspondence: joas.serugga@hud.ac.uk
}

Received: 24 March 2020; Accepted: 21 April 2020; Published: 28 April 2020

\begin{abstract}
The recent notable emergence of a body of research in requirements management on one hand and benefits realisation has contributed to addressing a growing need for improved performance in Architecture, Engineering and Construction (AEC) projects. However, front end design (FED) as one of the vital processes in the project life cycle and delivery has attracted limited research to date within this understanding. This paper aims to map current evidence on requirements management in facilitating benefits realisation from an FED perspective. This is to bring about an updated and unified position on requirements management for its impact on design decision making. A systematic review of the literature covering the last ten years (2008-2018) aims first to build understanding and support identification of these emergent conceptual positions and secondly underscore essential requirements and their categorisations that impact on design discourse in FED. One hundred sixty-one peer-reviewed journal papers in the areas of benefits realisation and/or requirements management and/or FED based are identified on a pre-determined inclusion and exclusion criteria. Thirty-six requirements are identified as important in influencing use case changes important in design decision making broadly grouped into nine major categories. Following analysis, this research finds little evidence supporting an integrated requirements management practice and understanding to support design decision making. The research further finds bias in current research discourse towards four requirements categories (technical, economics, governance and environment); and 14 requirements, dominated by three strategic values, collaboration and project governance, with over $80 \%$ share of literature. The least 14 requirements such as "flow of spaces, social status/aspiration, mobility and integrated design" among others only account for less than $10 \%$ of literature. The authors argue for new research to bridge this gap, highlight the essential role of requirements management and broaden understanding to improve benefits realisation, particularly for FED processes.
\end{abstract}

Keywords: requirements management; front end design; benefits realisation

\section{Introduction}

A significant part of project performance relates to how well projects deliver continuously on benefits in use (the perceived and derived benefits), throughout its lifecycle. As user preferences continue to become complex as a result of new and emergent contextual factors and user needs, there is an increasing need for new research into project value performance for the future [1]. At the heart of this increasing need, however, is the delivery of intended project benefits [1-6]. Projects in a benefits realisation sense need to adequately capture, define, implement and evaluate their intended benefits continuously for better project performance $[4,5]$. Benefits realisation, therefore, aims to 
harness organisational resources through planning and management in supporting change that delivers effectiveness and efficiencies in organisational processes for successful projects, programs and portfolios [5,7]. It is essential to highlight that at the heart of both benefits, realisation and requirements management is a change and control process that should support decision making. At the same time, however, increasing complexity in user preferences means that planning and management of benefits need to keep pace through continually building new understanding and evolving practice during project delivery.

At the same time, there is increasing research in requirements management as a critical driver for benefits realisation [8-12]. Again its argued that project requirements need to be adequately captured, defined, transformed, delivered and evaluated during project delivery [8-10]. Project performance, therefore, appears to depend on how well project requirements are managed throughout the project's processes. For successful requirements management, practice dictates that stakeholders should engage through participatory and collaborative processes [13], as in benefits realisation processes. Despite this understanding, research such as Burger, White [14] and Tezel, Koskela [1] point to continuing underperformances in Architecture, Engineering and Construction (AEC) across many life cycle processes. This has been attributed in part to the insufficiency in the understanding of processes and fragmented practice on the one hand; and inadequacy in support tools on the other to support complex analysis of continually emergent and changing user needs [2].

Emergent research has also sought to demonstrate the critical role of Front End Design (FED) in contributing to broader project benefits [15-17]. FED is defined as the stage in the AEC project development cycle in which project processes define the project idea/purpose, scope and goals; the business case including any feasibility, funding, stakeholder, risk, benefits, value and execution planning as well as the development of any outline designs [18-21].

Therefore, as a process that espouses the early stages of project development, FED stands at the critical interface between requirements management and benefits realisation in particularly in capturing and defining changing user needs. It has, however, been argued that FED remains understudied and unstructured on the one hand [2,22] while on the other, it is information-intensive-reliant on knowledge sharing [23] and presenting the most critical opportunities for benefits co-creation [16] in a project's lifecycle. However, a lot of downstream project underperformances can be from insufficiencies in FED processes [24]. This means that project processes in FED that are essential in ensuring delivery of early and intermediate project benefits through managing project requirements that can be optimised through a structured approach.

Current bodies of research in requirements management in FED on the one hand and benefits realisation on the other are, however, in the main discussed separately in research at present. However, a converged understanding is vital in drawing focus on the intricate complexity of project delivery that's mainly influenced by the structure and agency (as understood in social sciences) nature of design practice. The separate research realms also continue to increase the gulf between them, yet clarity is now vital, in a converged new understanding of the essential complementary concepts in design. While a handful of recent research such as that Kagioglou and Tzortzopoulos [3] have attempted to explore the concept of structure and agency as a key conceptual understanding in benefits realisation, much more research is needed to bring this into AEC. Kagioglou and Tzortzopoulos [3] highlight 'structure' as "action and the actors involved in both undertaking and enacting processes" while 'agency' is the representation of the different stages and phases in design. This places the understanding of 'structure' of design as the underlying basis of the 'concepts and logic of analysis and synthesis', a critical process in the definition and understanding of requirements in the design process [25]. Moreover, although recent research in benefits realisation and requirements management concepts represents a fresh approach to project benefits delivery, both require reformulation in the perspective of FED as an intermediate benefit delivery stage essential for the realisation of the broader project and organisational benefits. 
This paper, therefore, aims to map current evidence on requirements management and benefits realisation with a focus on those factors that impact on them from the perspective of FED through a systematic literature review. The review aims to explore emergent conceptual positions by understanding how requirements are applied and categorised in FED and recast them in a new updated and unified position with a focus on supporting structured design decision making for improved benefits delivery in the dynamic and inherently contextual FED. In fulfilling this aim, the paper presents first the conceptual understanding of benefits realisation and requirements management and secondly recast these in an FED perspective. This informs the discussion on the thirty-six design requirements identified in this review in their nine categorisations.

The paper thus follows the following structure: Following on from Section 1, which introduces the concepts more generally, Section 2 explores the theoretical conceptions of benefits realisation and requirements management. In drawing this from an FED perspective, the review aims to identify gaps in research and practice that contribute to poor decision making. Section 3 presents the research methodology, including the research questions. Section 4 discusses the findings of the research, and, finally, Section 5 discusses the results, including a look at their implications for both industry and research as it concludes. The section also identifies limitations for the research highlighting future opportunity areas.

\section{The Dynamics of FED}

Project requirements in design are influenced by the structure and agency of design practised as understood in the social sciences. The subject of structure and agency in its influencing role for users and stakeholders in changing their individual and organisational structures and preferences; such as in innovation adoption and consensus building is a subject of intense and increasing ongoing debate in the social sciences [26,27]. In design practise, and the broader AEC project implementation [3], however, these two elements are essential to integrated project delivery (IPD). Structure in this understanding refers to the processes during design, while the collaborating stakeholders, their preferences and influences represent the agency. Requirements understanding in this study, therefore, incorporates the perspective of the influencing role of agency which means a broader understanding of project requirements from and to the individual, organisational, economics, geopolitics, sociocultural and environmental factors among others; and how these influence FED processes (structure) in contributing to benefits realisation.

Authors such as Burger, White [14], Almqvist [28] and earlier George, Bell [29] join a growing body of research to highlight the vital role of FED in the efficacy of benefits realisation in AEC projects. This body of research argues that FED is the starting point in the realisation of project benefits, offering opportunities for requirements management and optimisation. FED is thus seen as one of the critical stages in a project lifecycle [30]. According to this emergent body of knowledge, vital decisions that impact on downstream project performance are usually made in FED. Other authors such as Smyth, Lecoeuvre [31] highlight opportunities for value co-creation through stakeholder collaboration in this stage. Moreover, it is argued that costs relating to any design changes at this stage can be a fraction of those in later stages of project implementation. Fuentes and Smyth [16] highlight, however, that in terms of benefits realisation, more understanding is needed into the exact links between value co-creation and benefits realisation. It is argued in other research that continuing value underperformances in the AEC stem from limited collaboration among stakeholders, [1], optimisation and modelling of processes [2,17] and insufficiencies in the body of evidence underpinning design decision making [28] among others. This highlights, on the one hand, the inherent inadequacies in the current management of project requirements in as much as they account for contextual influences; and opportunities for their management and optimisation in FED processes on the other.

Such insufficiencies, according to Oh Eun, Naderpajouh [32] are what contributes to failures in later processes that manifest as waste. Moreover, authors such as Halttula, Haapasalo [33], and Gibson, Bingham [17] argue that there is a direct link between such wastes in downstream processes and 
insufficiencies in earlier FED processes as a result of ill-defined requirements; a position reinforced by later Kukulies and Schmitt [34]. This essentially suggests that a rigorous requirements management process in FED is essential in the delivery of project benefits [8]. Requirements understanding is a crucial element of the body of knowledge essential for FED; and structuring requirements management processes is therefore essential in the information flow and exchanges thereof [29]. The study by George, Bell [29] highlighted how this structure impacted on project scope definition, process, resource and risk management and planning, and fostering of collaborative environments aspects which impact on project communication and information flow. It, therefore, appears that improving the requirements management processes in FED translates into improved value delivery for the end-user [8]. This approach to improved FED also presents opportunities for the design process to uncover unknowns in the process of defining the solution in a structured way [17]; as well as to context-specific influences on designs [35] drawing to the many benefits of a structured FED. While research in this area appears on the increase, there is a gap between this body of research and the intricacy of requirements management in practice, much of which remains rational mainly and inadequate for the increasing complexity [2].

\section{Research Methodology}

This research adopts the systematic review approach proposed by Xiao and Watson [36] for standalone reviews to describe the state of the art in answering the research questions. In proposing their approach, the authors highlight that literature review is an essential and present feature of academic research as they link present and past research in order to form a foundation for new frontiers in the research of the specific research area, bring to light the breadth and depth of and identify gaps in present research and understanding. Literature reviews also, according to Paré, Trudel [37] are vital in evaluating the validity and quality of existing research against emergent conceptualisations as a basis of building new understanding through identifying weaknesses. Rigour in a literature review, therefore, relies on replicability, reliability and validity of any new frontier that addresses new hypotheses and theories; something that sets apart systematic literature reviews from traditional ones [36]. The collation of collective theoretical insights from existing research is key to new knowledge free from bias, chance effects and improved legitimacy of new positions [38].

\subsection{Aim and Research Questions}

The need for better performance of AEC has spurred interest in strategies of realisation of benefits across the AEC sector. At the same time, its increasingly recognised that the successful delivery of these benefits hinges on a structure and understanding of the requirements management process. However, this is impacted by changing user needs from various factors. While there is an emergent body of research in both areas, a lack of converged and coherent position on both conceptualisations on the one hand and limited understanding of the crucial factors influencing the practice and implementation of the two concepts in AEC on the other means new research is needed. This research seeks to bring about a converged understanding of the state of the art, which is then recast from an FED perspective. The aim is, therefore, to explore current research positions and describe the state of the art in requirements management, including factors and categorisations important for benefits realisation from an FED perspective. The review, therefore, answers the following research questions:

RQ1-What is the state of the art in benefits realisation and requirements management in the design of AEC projects?

RQ2-What potential requirements categorisations influence requirements definition in FED? RQ3-How do these factors impact on benefits realisation in FED?

\subsection{Search Strategy}

The Xiao and Watson [36] approach to search is adopted for this research. The empirical analysis that follows is based on pre-defined search criteria and review objectives. This means defining the 
bounded space for search, including electronic and printed databases. The broad approach involved an initial retrieval of relevant results followed by snowballing in which other meaningful studies references form part of an additional search. This approach aims to add additional studies that would otherwise not be reflected in the original search.

The search criteria adopted the following:

$\mathrm{C} 1$-a string of keywords on benefits realisation, including "project requirement" OR "benefits realization" OR "benefits realisation planning" OR "benefits capture" OR "benefits elicitation" OR "benefits management".

C2-a string relating to requirements management including "requirements management" OR "project requirement" OR "requirements engineering" OR "requirements elicitation" OR "requirements capture" OR "Design Requirements" OR “User Requirements" OR “Customer Requirements" OR "Requirements transformation".

C3-a string relating to Front End Design including "front end design" OR "front end planning" OR "early-stage design" OR "conceptual design" OR "conceptual design Stage" OR "Front End".

$\mathrm{C} 1$ and $\mathrm{C} 2, \mathrm{C} 1$ and $\mathrm{C} 3, \mathrm{C} 2$ and $\mathrm{C} 3$, and $\mathrm{C} 1, \mathrm{C} 2$ and $\mathrm{C} 3$.

The steps undertaken are discussed in the below section and summarised in Figure 1. The process illustrated takes a 4-step guide, including (1) - Identification: In which the research aims to establish all possible articles broadly relevant to this research study. This process searched in databases including Google Scholar, Scopus, Web of Science and EBSCOhost as the most standard databases for researchers. Issues of accessibility of journals and increased risk of duplication rendered databases such as ASCE inappropriate. The search terms (see Table 1) were limited for the years 2008-2018. (2)—Screening: in this process, the research sought to apply exclusion criteria to identify data including establishing whether the study was or not a peer-reviewed publication, published between 2008-2018, written in English and that the study was or not focused on the review concepts. (3)—Eligibility-in this stage, the research sought to apply an eligibility criterion including ascertaining that any articles included are peer-reviewed publications on the specific concepts of this research, is in English the full text is available among others. The first read through the full research articles was to support quality and eligibility evaluations. Publications in high impact peer-reviewed journals were deemed high quality and included in the review. On the contrary, presentations, conference papers from low impact factor publications were excluded notwithstanding quality conference papers of high-quality conference proceedings; and finally, (4) - Inclusion-in which the research finally included the most relevant studies, particularly those that more closely relate to the concepts and have been referenced in the reviewed articles and comply with the exclusion rules. This process was iterative and sought to explore additional relevant studies with alternative methods and examples. At all times, this stage followed a quality assessment criteria illustrated in Table 1.

Rigour and validity are a vital aspect of literature review, and, as such, this paper has sought to embed best practice in supporting these such as (1) adopting a structured research design (see Figure 1), (2) advancing independence coding of review data [39]) and (3) assessment of quality of the reviewed studies (see Table 1) as adopted by Inayat, Salim [13]. 


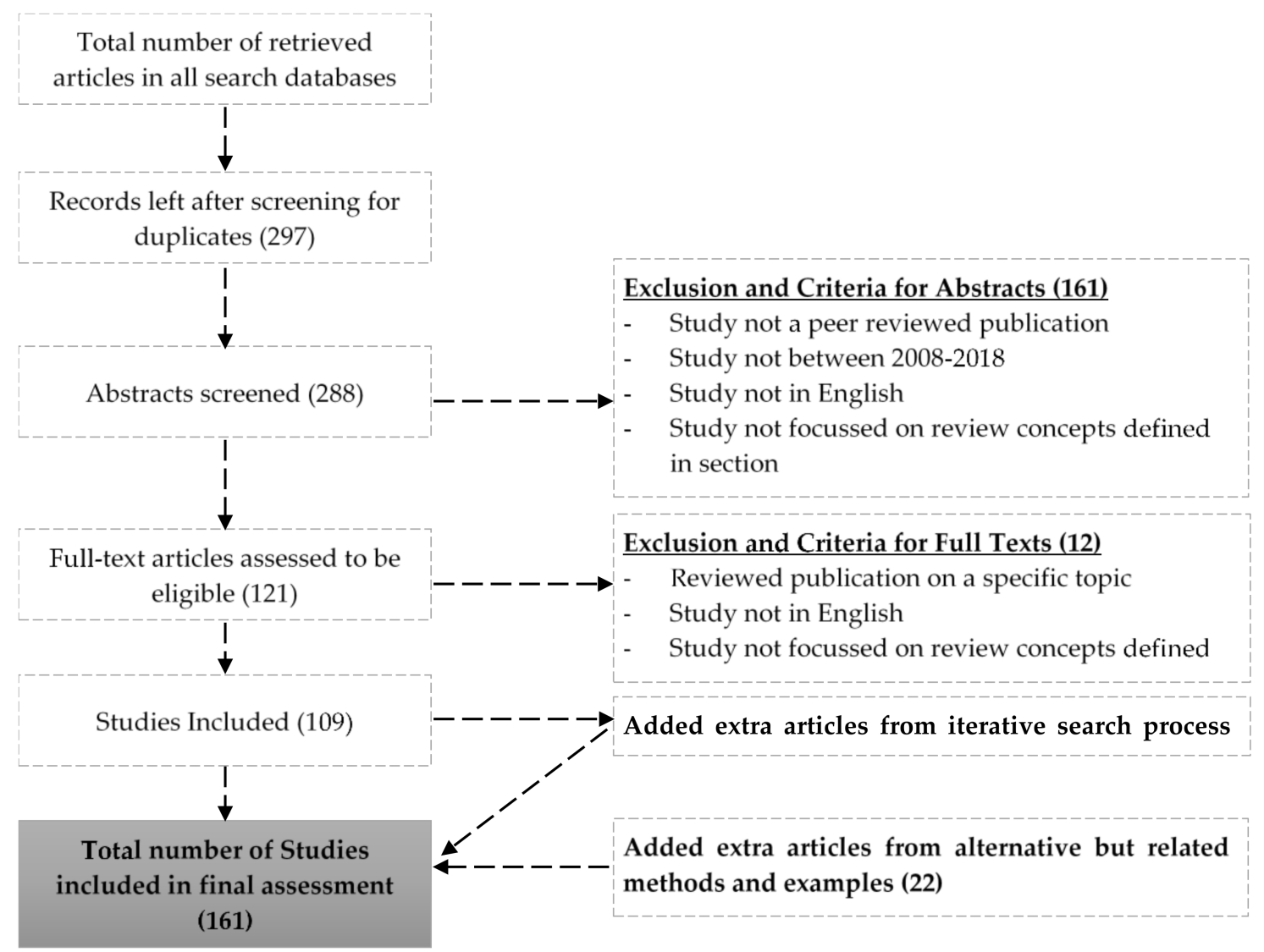

Figure 1. The research approach for exclusion and Inclusion-Adapted from Xiao and Watson [36].

Table 1. Assessment of quality.

\begin{tabular}{ccc}
\hline Criterion & Grade Criteria & Grade \\
\hline C1-Clarity of aims and objectives & $(1,0.5,0)($ Yes, Nominally, No) & 151 Studies, 94\% \\
C2-Focus and context of research & $(1,0.5,0)($ Yes, Nominally, No) & 150 Studies, 93\% \\
C3-Clarity in research findings & $(1,0.5,0)($ Yes, Nominally, No) & 153 Studies, 95\% \\
C4-validity and rigour of research & $(1,0.5,0)($ Yes, Nominally, No) & 151 Studies, 94\% \\
\hline
\end{tabular}

In the criteria illustrated in Table 1, an ordinal scale is used to grade the studies including establishing the level of clarity in their aims and objectives, focus and context of the specific research about the defined concepts for this research, clarity of research findings and finally grading the validity and rigour of the selected studies. This process was shared among research partners both within and outside of the study team to bring about objectivity to the research. To assist in subsequent evaluations, the papers were analysed for each of the nine categories and thirty-six factors alongside the year of publication, key concepts and research sector, geographical context, and methodology employed for the study. A summary of the important case studies highlighting the essential requirements and their categories is shown in Appendix A, while the full table of results is in Appendix B and the overall results are summarised as follows: Overall, there is a marked increase in research around the key concepts over the last decade as seen in Figure 2. Only a handful of the 161 articles appear in the years 2008 to 2014. 


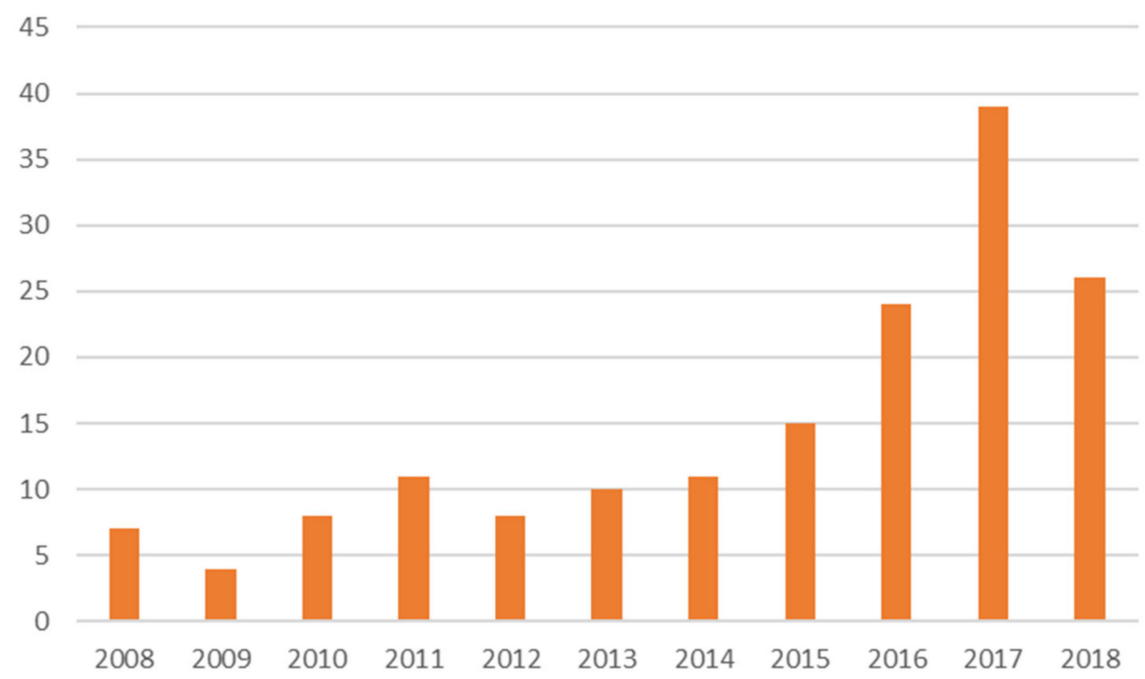

Figure 2. Distribution of resources over the decade.

The full table in Appendices A and B, and the overall results are summarised as follows:

- The majority of analysed papers were in the construction sector ( $81 \%)$, while $10 \%$ were in the IT sector. Other sectors including the Engineering design (4\%), New Product Development (3\%) and Product Service Systems Design (2\%) are all summarised in the pie chart in Figure 3.

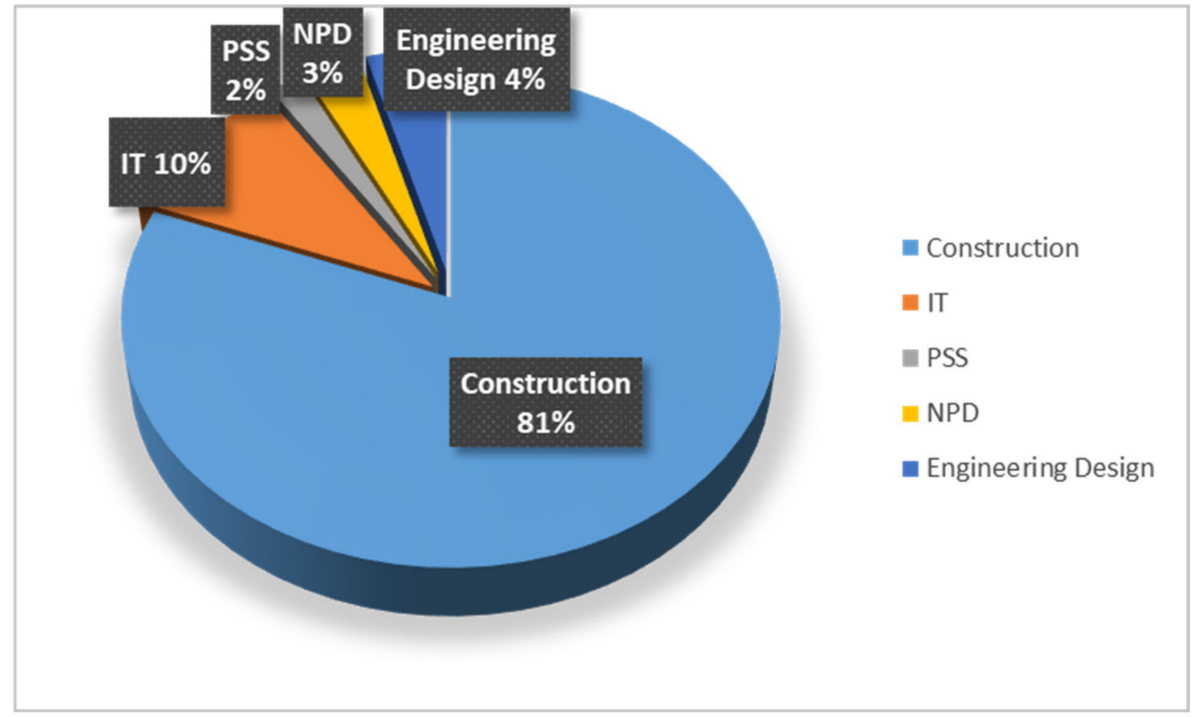

Figure 3. Research sectors used in the study.

- The study resources covered the leading journals in the areas of AEC, facilities, but also those in IT, sustainability, manufacturing and requirements engineering. Over $70 \%$ of articles were from AEC journals resources as summarised in Figure 4. 


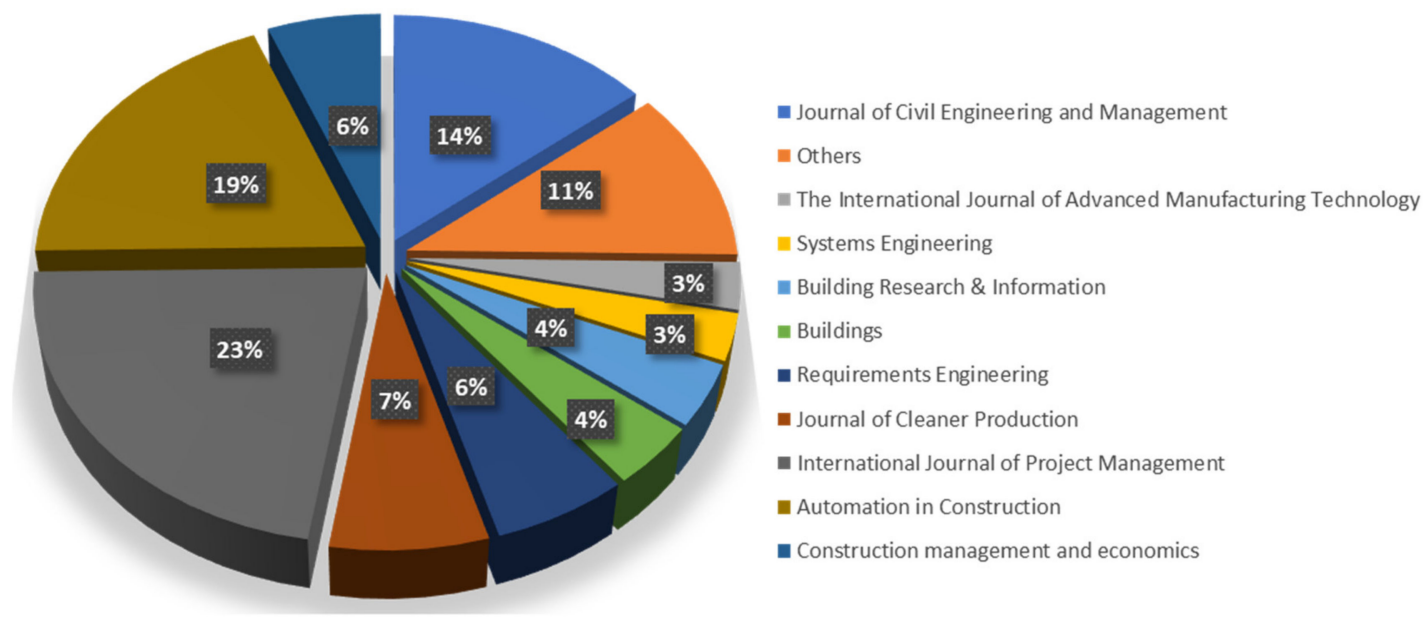

Figure 4. Summary of Journal Resources for study.

- Half of the studies had a focus on value management, while only $3 \%$ discussed benefits realisation (see Figure 5). A quarter explored FED as a concept important in value delivery, while $22 \%$ had a focus on requirements management. These studies were not necessarily exclusive to a particular conceptualisation, meaning that while about $80 \%$ were, the rest covered more than one of these conceptualisations.

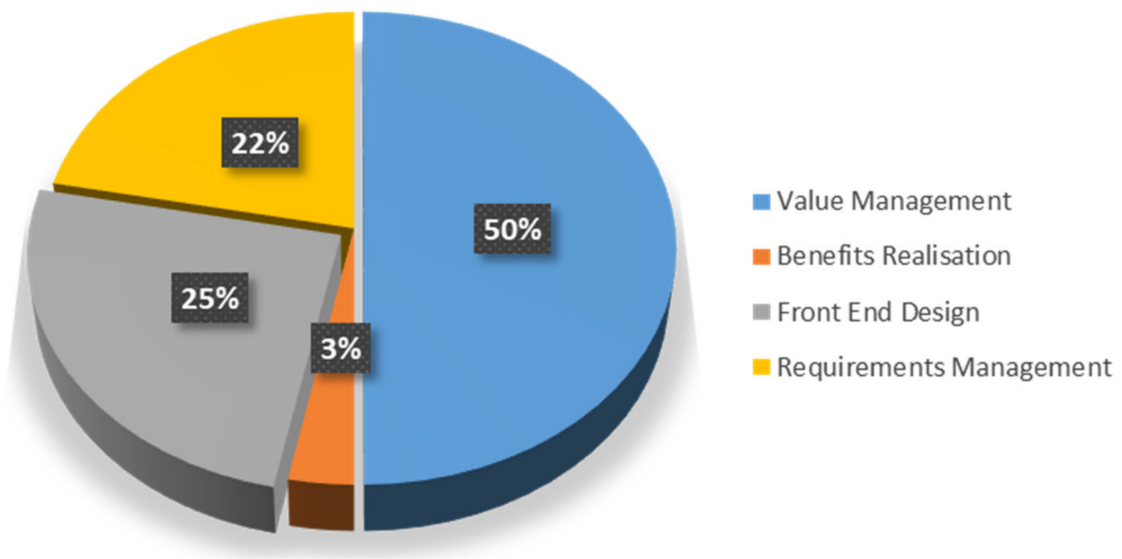

Figure 5. Distribution of concepts among study articles.

\section{Results and Discussion}

This study aims to advance the concept of benefits realisation in FED processes of AEC processes through building a foundational basis that supports understanding of project requirements. This understanding is essential for design processes to fully reflect the contextual dynamics of projects in fostering value generation [40]. The following sections explore some crucial aspects arising out of this study based on the results of the full summary in the table in Appendices A and B. This research's contribution to a new converged understanding firstly highlights some current definitions of the key concepts as summarised in Table 2. These definitions are essential to underscore meanings as widely applied in practice and research. 
Table 2. Summary of definitions of key concepts.

\begin{tabular}{|c|c|c|}
\hline Authors & Concept & Definition \\
\hline Pemsel, Wiewiora [41] & Governance & $\begin{array}{c}\text { A set of relationships between stakeholders and the distribution of rights and responsibilities among these } \\
\text { various stakeholders }\end{array}$ \\
\hline Ghosh, Amaya [42] & Knowledge Management & $\begin{array}{c}\text { The control of the organisational problem solution and adaptation capacity through a goal-directed } \\
\text { development and utilisation of the organisational knowledge base }\end{array}$ \\
\hline $\begin{array}{l}\text { Jallow, Demian [43], The Office } \\
\text { of Government [44] }\end{array}$ & Requirements Management & $\begin{array}{l}\text { The process of elicitation, documentation, organisation and tracking requirements information and } \\
\text { communicating across the various stakeholders and project teams as RM. }\end{array}$ \\
\hline \multirow[t]{2}{*}{ Xiaochun Luo, Shen [45] } & Functional Performance & $\begin{array}{c}\text { A structured requirement analysis process, in which client requirements are firstly defined with functions } \\
\text { and relevant evaluation criteria }\end{array}$ \\
\hline & Value Management & $\begin{array}{c}\text { Defining what 'value' means to a client within a particular context by bring the project stakeholders together } \\
\text { and producing a clear statement of the project's objectives }\end{array}$ \\
\hline Samset and Volden [46] & Project Governance & $\begin{array}{c}\text { The processes, systems, and regulations that the financing party must have in place to ensure that projects } \\
\text { are successful }\end{array}$ \\
\hline ul Musawir, Serra [40] & $\begin{array}{l}\text { Benefit } \\
\text { Benefits Realisation } \\
\text { Management }\end{array}$ & $\begin{array}{l}\text { A flow of value that occurs when customers use project outputs } \\
\text { A set of processes that ensure that projects, programs, and portfolios embed the requirements of business } \\
\text { strategies into business-as-usual, in order to create value in a meaningful and sustainable manner }\end{array}$ \\
\hline \multirow[t]{2}{*}{ Pegoraro and Paula [47] } & Requirement & $\begin{array}{c}\text { A statement that prescribes features that a product or service must have to satisfy demands or to achieve } \\
\text { project stakeholders' goals }\end{array}$ \\
\hline & Design Solution & decision or action is chosen to meet the design requirements, which must be limited by the specifications \\
\hline
\end{tabular}




\subsection{Requirements Management and Benefits Realisation}

While it can be argued that the individual concepts of benefits realisation, requirements and FED have been developing over the years, what the results indicate is that they have been doing so independently and individually with limited linkage. As a highlight, for example, the plethora of research into requirements management [43,48,49]; has been limited in its explicit adoption of benefits realisation principles [40]. Studies such as ul Musawir, Serra [40] point to potential benefits in project governance and stakeholder management two of an important array of requirements for project success. It is, however, important to highlight that such studies have been unable to cover the full spectrum of project requirements essential in project benefits delivery in FED.

Moreover, despite these and other benefits, there is limited evidence of convergence in the practice and understanding of requirements management as a critical process in benefits realisation practice [43]. At the same time, it is widely acknowledged that at the centre of a requirements management process is a change and control process (see Figure 6) in which understanding of requirements runs alongside a value management process [43]. The conceptual model consolidates the understanding of benefits realisation on the one hand and requirements management in a FED perspective informed by current conceptual positions from the papers studied.

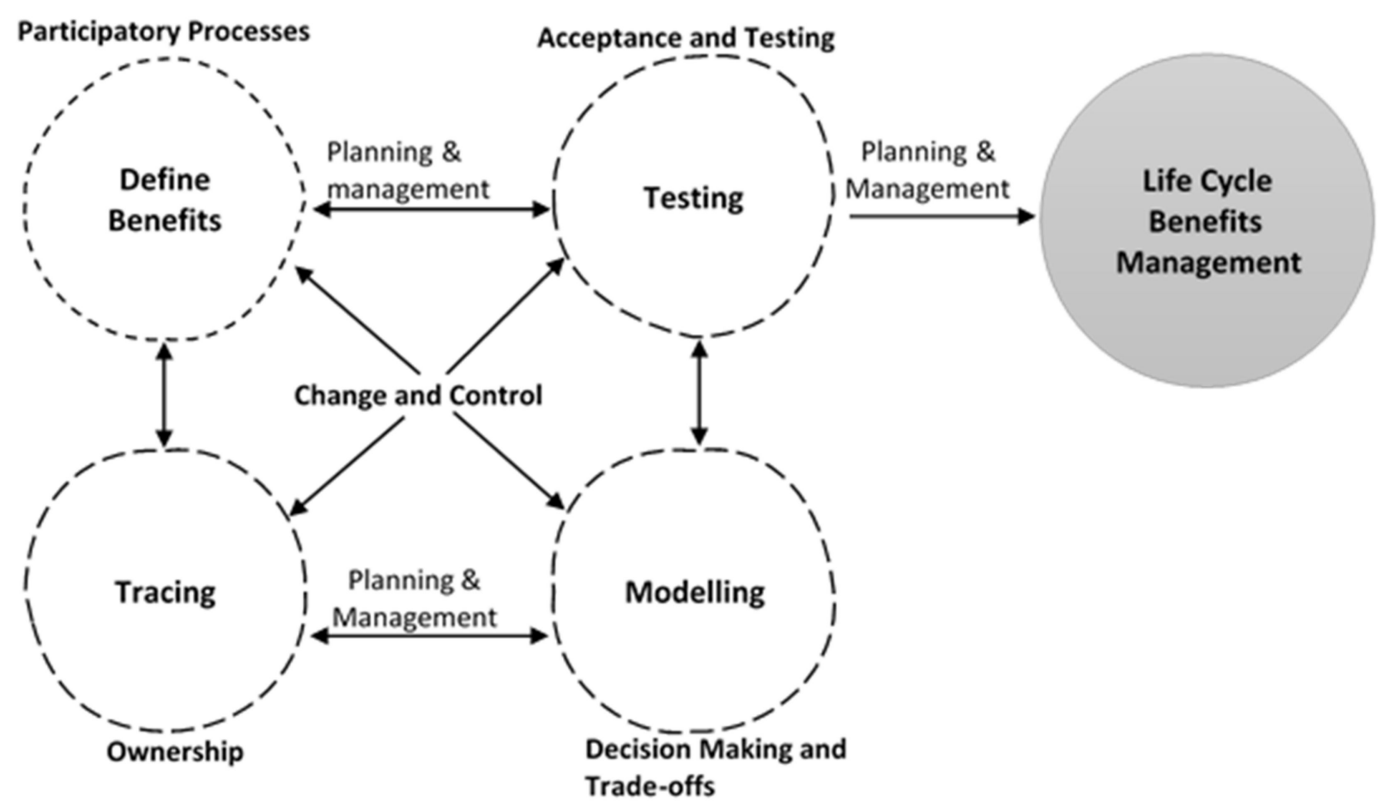

Figure 6. The Change Control Model for requirements management and benefits realisation in an FED perspective.

Change control is vital in the crucial dynamics of benefits definitions, testing, modelling and tracing. This is also observed to be key to benefits realisation. The absence of a conceptualisation convergence in practice means potentially that decision making in FED lacks the full spectrum of support it needs to harness and deliver project benefits [18,50]. Its however necessary to acknowledge research positions such as those by ul Musawir, Serra [40], Elf and Malmqvist [51] and others point to potential benefits of benefits realisation as an anchor in the requirements management process. It is thus essential to recast these crucial dynamics in a FED perspective in a manner that supports further understanding of these key conceptualisations as is demonstrated in Figure 6. On the one hand, the model captures the essential elements of requirements and benefits ownership within a participatory process. This creates space for benefits and requirements to be defined while ownership ensures that they're traceable. On the one hand are the trade-offs in decision making and testing and acceptance of the requirements and benefits as they address the project objectives on the other. Both sides work iteratively and are part of the essential planning and management in realisation of 
wider lifecycle project benefits. With this, requirements and benefits can be modelled and tested to again fit the project objectives. In this illustration, it is demonstrated that the key conceptualisations are essential in drawing out project lifecycle performance through integrating participatory processes where participants accept ownership during decision making and in which defined benefits can be modelled defined, modelled, traced and tested and for project lifecycle performance.

The key project requirements are summarized in Figure 7, including essential categories of economics, socio-culture, health and safety, technical considerations, project lifecycle performance, occupancy factors, geopolitics, environmental considerations and governance.

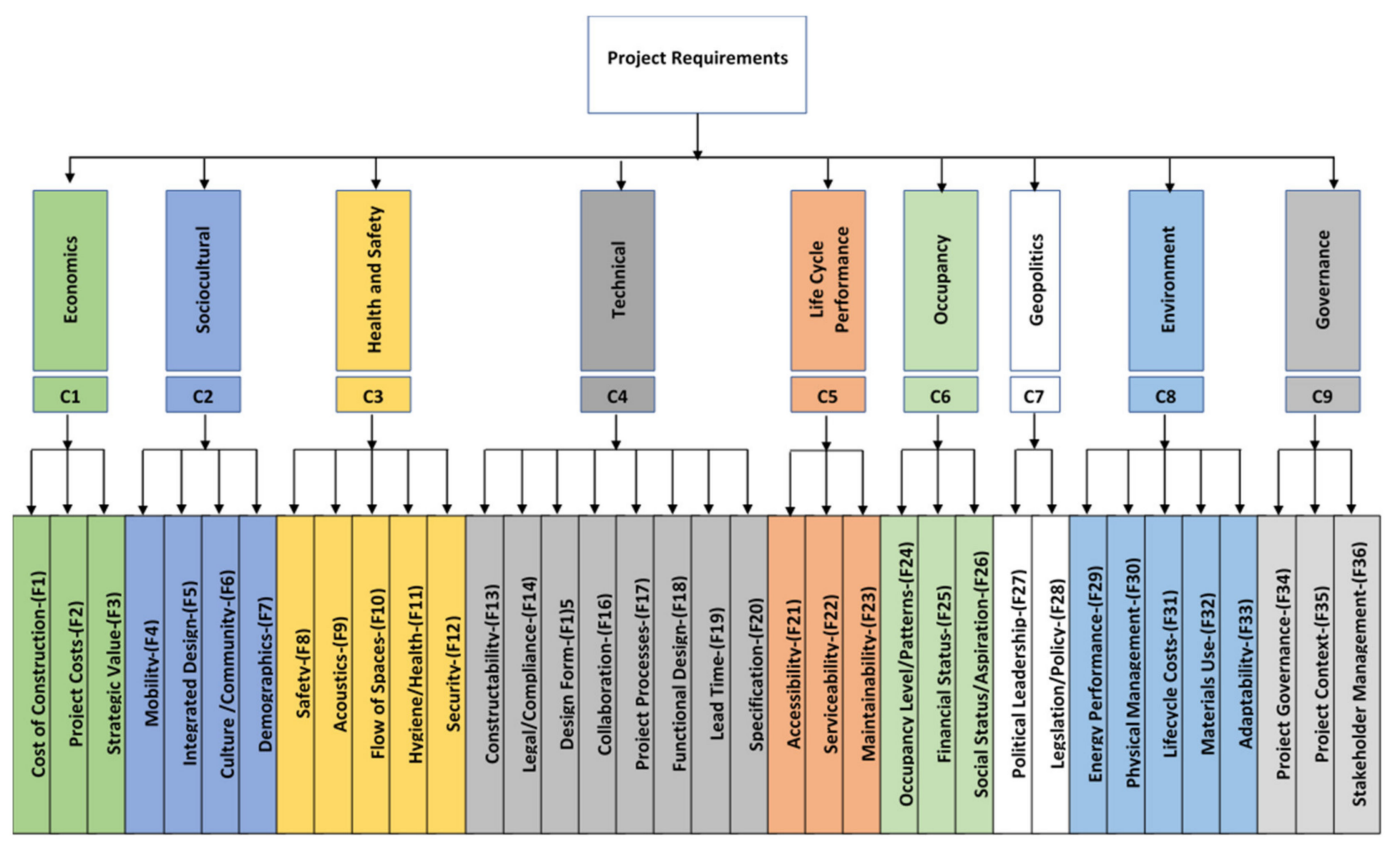

Figure 7. Summary of categories and factors of Design Requirements.

The categorisations are based on studies' representation of requirements throughout the review. Some studies have used related or similar meanings that this table collates to support the categorisation. For example project governance [40,41,46,52], project context $[31,53,54]$ and stakeholder management [55-58] are all requirements relating to governance and are grouped as such. Similarly, the Economic categorisation groups requirements relating to cost of construction, project costs, i.e., the project implementation costs not directly relating to construction [1,59,60]; and strategic value $[40,61,62]$ of the project all of which impact and directly translate into economic viability requirement of a project. On the other hand, life cycle costs, energy performance materials use adaptability of design over its life or the management of the physical setting of design all impact on the environment and are grouped as such. This is supported by author considerations in such studies as Cavka, Staub-French [63], Sousa-Zomer and Cauchick-Miguel [64], Vezzoli, Ceschin [65] and Jay and Bowen [66] among others. The rest of the categorisations, including sociocultural, health and safety, technical, lifecycle performance, occupancy and geopolitics, have been developed on a similar basis. The categorisations in Figure 7 are supported by the summary in Table 3 of some of the crucial studies that capture, represent and inform this study's taxonomy of the major requirements. All the requirements categories are considered among the thirteen selected studies ranging from construction, IT, Product-Service Systems and Engineering design that had a case study research methodology: highlighting the practical their nature. This highlights the importance of widening scope in other sectors in drawing to the understanding of the essential dynamics inf FED in different contexts and applications. 
Table 3. Selected literature on the requirements categorisations.

\begin{tabular}{|c|c|c|}
\hline Author & Category & Research Questions/Goals \\
\hline Cavka, Staub-French [63] & $\begin{array}{l}\text { Technical, Economics, Governance, } \\
\text { Environment, Health and Safety, } \\
\text { Life Cycle Performance }\end{array}$ & $\begin{array}{l}\text { A study to understand and facilitate processes of developing and formulating Building } \\
\text { Information Modelling (BIM) requirements to support the lifecycle of their assets through an } \\
\text { iterative approach to the identification and characterisation of owner requirements }\end{array}$ \\
\hline $\begin{array}{l}\text { Sousa-Zomer and } \\
\text { Cauchick-Miguel [64] }\end{array}$ & $\begin{array}{l}\text { Governance, Environmental, Technical, Health } \\
\text { and Safety, Life Cycle Performance }\end{array}$ & $\begin{array}{c}\text { The study investigating Product Service System (PSS) applied to sustainable design during } \\
\text { conceptual design }\end{array}$ \\
\hline Locatelli, Mariani [67] & $\begin{array}{l}\text { Economics, Technical, Geopolitics, } \\
\text { Governance, Sociocultural }\end{array}$ & A study into new ways to select, plan and deliver infrastructure in corrupt project contexts \\
\hline Mok, Shen [56] & $\begin{array}{l}\text { Governance, Economics, } \\
\text { Technical, Sociocultural }\end{array}$ & $\begin{array}{c}\text { An investigation of stakeholder complexity and understanding how major pitfalls in cultural } \\
\text { building projects from a stakeholder perspective are crucial to the successful management of } \\
\text { these projects }\end{array}$ \\
\hline Osei-Kyei and Chan [68] & $\begin{array}{l}\text { Economics, Governance, Geopolitics, } \\
\text { Technical, Occupancy }\end{array}$ & $\begin{array}{c}\text { A study into the success and failure factors of Public-Private Partnership Transport } \\
\text { Infrastructure in Sub-Saharan Africa }\end{array}$ \\
\hline Palm and Reindl [69] & $\begin{array}{l}\text { Environment, Economics, Geopolitics, } \\
\text { Life Cycle Performance }\end{array}$ & A study into renovation processes for reduced energy consumption in front end design \\
\hline Vezzoli, Ceschin [65] & $\begin{array}{l}\text { Environment, Economics, Geopolitics, } \\
\text { Sociocultural, Technical, Governance, } \\
\text { Health and Safety, Occupancy }\end{array}$ & $\begin{array}{l}\text { A state of the art look into user satisfaction and acceptance of Sustainable Product-Service } \\
\text { Systems solutions and how industrial partnerships and stakeholder interactions can be } \\
\text { designed for environmental and socio-ethical benefits, socio-technical change and } \\
\text { transition management }\end{array}$ \\
\hline Buyle, Audenaert [70] & $\begin{array}{l}\text { Environment, Economics, } \\
\text { Geopolitics, Governance }\end{array}$ & $\begin{array}{c}\text { An investigation into scenarios to improve the environmental profile of new buildings in the } \\
\text { Flemish/Belgian context }\end{array}$ \\
\hline Shackleton, Hebinck [71] & $\begin{array}{l}\text { Occupancy, Economics, Technical, } \\
\text { Environment, Geopolitics, Life Cycle Costs }\end{array}$ & $\begin{array}{l}\text { A study into how policy can foster urban forestry and greening through a regime of } \\
\text { maintenance, use and appreciation of trees on private homesteads of residents of new and } \\
\text { older low-income suburbs as well as informal housing areas }\end{array}$ \\
\hline Thomson, Austin [72] & $\begin{array}{l}\text { Technical, Economic, Environmental, } \\
\text { Lifecycle Performance, Governance }\end{array}$ & $\begin{array}{l}\text { Examining the construction practitioners' collective cognition of value to determine how } \\
\text { their facilitation may bias this intent. }\end{array}$ \\
\hline Jay and Bowen [66] & $\begin{array}{l}\text { Technical, Economics, Environment, } \\
\text { Health and Safety, Sociocultural, Occupancy }\end{array}$ & A study of social housing value perceptions in South Africa \\
\hline Moodley, Smith [58] & $\begin{array}{l}\text { Sociocultural, Health and Safety, } \\
\text { Economics, Governance }\end{array}$ & $\begin{array}{c}\text { A study into ethics of construction practices including exploration of social contracts and } \\
\text { corporate responsibility }\end{array}$ \\
\hline
\end{tabular}


Current research has sought to provide a general understanding of practice in AEC practice such as in understanding value concepts and propositions in construction processes in regards to issues of structure and agency [72]. Thomson, Austin [72] explore the various factors that are important in drawing out project requirements such as the technical implications of collaborative processes, how lead times affect projects, functional issues in design as well as design form. The authors in their evaluative study also explore issues of environment, strategic value and economics of projects value, Economics alongside factors influencing lifecycle performance, among others. This study's focus is on how much these elements contribute to understanding of value from a practitioner's perspective. Similarly, the study by Cavka, Staub-French [63] through exploring BIM capabilities explores these requirements categorisations and characterisations in as much as they support processes that adequately manage owner needs in design processes. The study by Cavka, Staub-French [63] harnesses the iterative nature of design from an asset and facilities management perspective. In addition to the categorisations explored by Thomson, Austin [72], the Cavka, Staub-French [63] study looked to Health and Safety including the security and safety requirements that design processes had to take into account in consideration of owner requirements.

The evaluative study by Vezzoli, Ceschin [65] into sustainable product-service systems was important in highlighting design requirements relating to geopolitics in areas of policy and legislation. While geopolitics as an influence on design requirements and design practice, in general, is acknowledged throughout AEC practice $[61,71,73]$; the influence for policy/legislation on future of building spaces potentially as sustainable product services systems is none the less an essential factor in design decision making. This is not only because of the potential influence on such other factors as economic performance and sociocultural impacts of buildings among others; but also, how geopolitics impacts the overall lifecycle performance of these buildings as they continue to adapt to changing user needs.

The study by Osei-Kyei and Chan [68] drew on the requirements of occupancy alongside geopolitics, sociocultural and governance factors in Public-Private Partnership projects. The study highlights, on the one hand, the contextual element of requirements management drawing on the peculiarities of the sub-Saharan project context. The strong influence of governance in projects and geopolitics in these types of projects comes to the fore while the authors argue for actionable policy/legislation as guides, as well as the requirement for use and occupancy as communities, evolve both in their aspirations and status. This is not something identified in many research studies, particularly those in developed world project contexts where other contextual factors may be significant at play. This narrative is also highlighted by other studies such as Locatelli, Mariani [67], Mok, Shen [56] and others.

Overall, from Figure 8, the most common requirement category in the literature examined is the technical requirement $(26 \%)$ that looks at such factors as Constructability of the design, legal and compliance, design form and aesthetics, collaboration among project stakeholders, project processes, how functional a design is, project lead time and specification requirements. At $23 \%$, the economic performance of design follows with such factors as the cost of construction, project costs (Rent/Mortgage, management, contracts) and most importantly the strategic value that considers the residual economic performance of the design. Project governance, including such factors as project governance and knowledge governance, project context, and stakeholder management comes third at $18 \%$. The environmental performance of a design is fourth at $14 \%$ and includes considerations for a design's energy performance (sound, solar gain/loss, energy costs), physical management and landscaping, life cycle costs, materials use, and how a design adapts to changing use. These are followed by geopolitical, sociocultural (5\%), health and safety ( $4 \%$ ), lifecycle performance ( $3 \%)$ and lastly occupancy $(2 \%)$ factors. A similar narrative is seen for occupancy category where financial status dominates (56\%) over Occupancy Level \& Patterns (33\%) and Social Status/Aspiration (11\%) all summarised in Figure 9. 


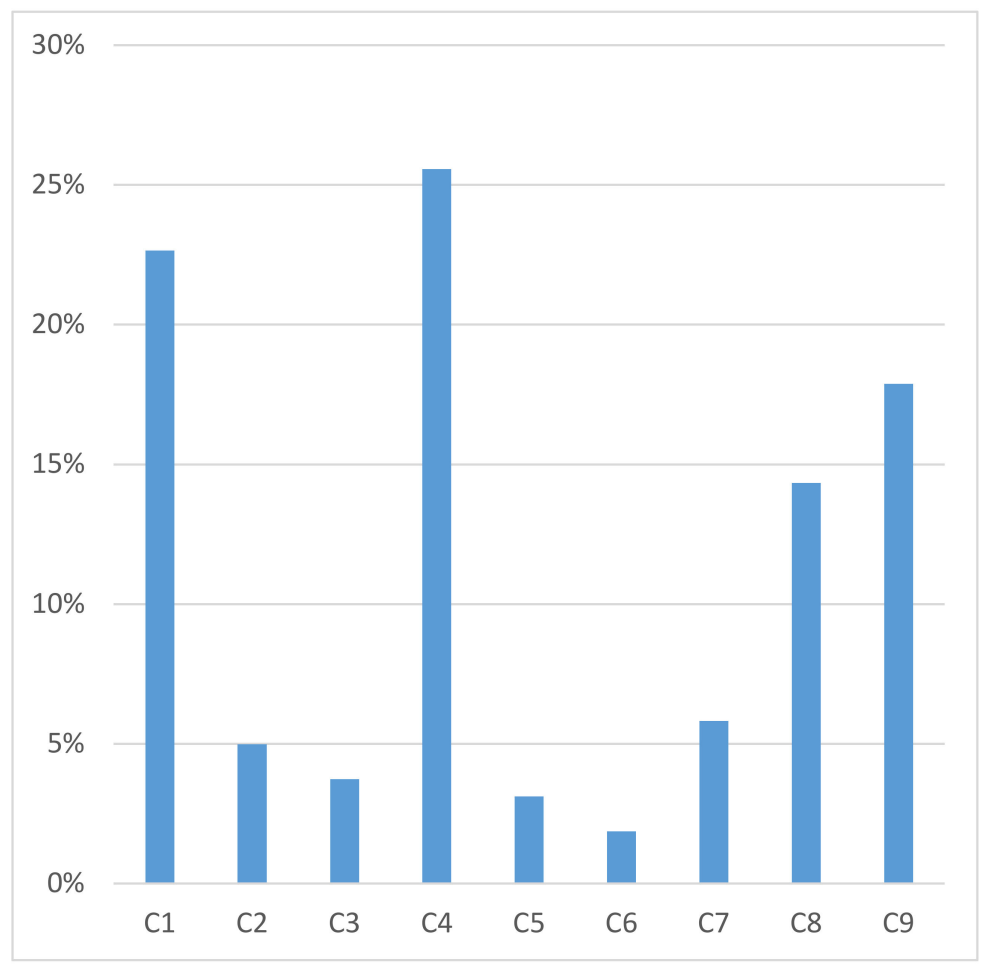

Figure 8. Requirement Category Ranking in FED.

It is notable that within the requirements categories, there appear some significant differences in consideration of factors impacting in the broad research base (see Figure 9). For example, while nearly half of all research is around the technical and economic factors, in the former, majority research about $80 \%$ is on strategic value while in the latter, collaboration among stakeholders is seen in over $55 \%$ of research considered followed by project processes but only with $14 \%$ of research. In the technical requirements, there is limited research for the requirements of specification of the design, legal and compliance issues, design form and aesthetics and project lead times all at $5 \%$. This is perhaps due to trends in AEC towards collaborative processes that have often been at the expense of other requirements within practice essential for the realisation of project benefits [74]. Similarly, while construction and project costs have been considered in recent years, much of current research emphasis appears on the strategic value of projects again at the expense of these other requirements necessary for the economic performance of a design from a benefits realisation perspective. Similarly, in the influence of geopolitics, a vast majority of research covers legislation and policy (61\%) as a vital influencing factor in the success of project benefits delivery while research is thin on political leadership that can be critical for many project contexts.

The sociocultural implications on design performance and benefits realisation are highlighted by authors such as Mok, Shen [56], Locatelli, Mariani [67] and Jay and Bowen [66] among others. However, while considerations for culture and community dominate current research $(67 \%)$, only $2 \%$ of research explores the influencing role of mobility as a factor important in design processes. Demographics only make $17 \%$ while integrated design is $8 \%$. This appears to suggest that research lacks a broader look particularly from a benefits realisation perspective of the essential aspects that impact on benefits perceptions while it might acknowledge some of the essential requirements factors that often draw on the contextual nature of project delivery. 


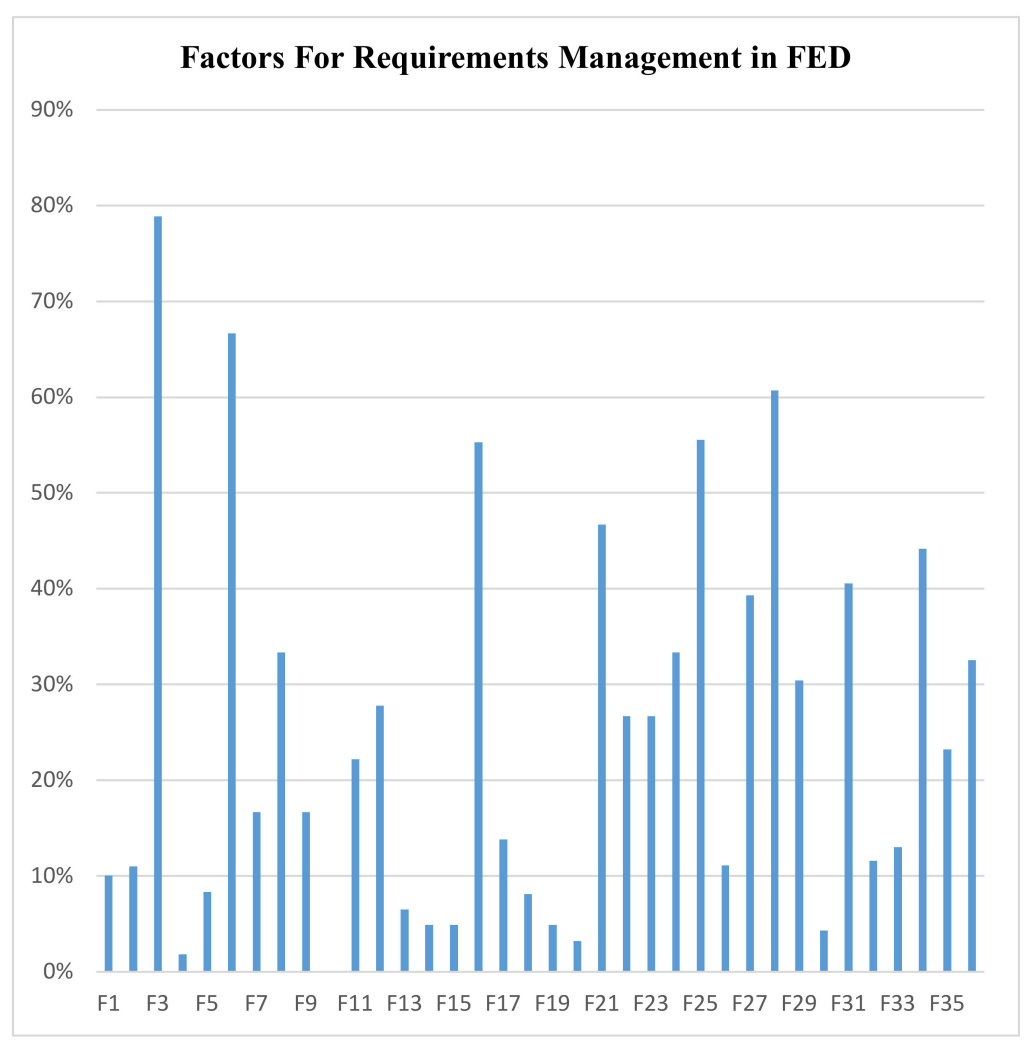

Figure 9. Requirements rankings in FED.

\subsection{Requirements Categorisations for FED}

Literature highlights nine influential categorisations important for consideration in design processes. In answering the research questions, this section discusses the requirements category findings.

\subsubsection{Economics}

Leśniak and Zima [60] for example highlight that cost of construction may be impacted by such factors that relate indirectly to the environmental performance requirements, comfort, and quality that the design deliverers to the end-user, and those relating the lifecycle of a building impacting on such things as the cost of the choice of materials to be used. Lin, Chang [75], on the other hand, highlight the costs of those essential resources in production elements in construction such as the price of land and labour. It is notable, however, that economic performance extends to stakeholders' economic influences that ultimately link to their derived benefit of the design. Requirements relating to the cost of construction, which will play an essential role in such things as the sale or rental price, are economic decisions. How well stakeholders perceive these moreover can depend on the general health of the economy [66]. During economic downturns, for example, different perceptions might be drawn than from economic boom times.

\subsubsection{SocioCultural}

The effect of culture and community as essential requirements in the realisation of project benefits has been explored widely in research [58,76,77]. Sousa-Zomer and Cauchick-Miguel [64] however explore issues of PSS in facilitating sociocultural integration in as far as facilitating mobility. Whereas the authors refer to 'mobility' in their study lending to movement in the shareable bicycle project, their concepts of economic empowerment do lend to mobility as understood in the social sciences in communities. Surlan, Cekic [78] in their study, highlight the importance of mobility in value in how it relates to local contexts. While these authors attempt to explore mobility as an important requirement in project benefits realisation, research is limited in the area in terms of its 
impact and relationship with other requirements, and similarly to the requirement of demographics. Value perception is a social construct as pointed in research [72].

Social influences on intended and perceived benefits can, therefore, in turn, be influenced by societal and cultural changes. Stakeholder requirements relating to the energy performance of a home, or how integrated the design is with its wider surroundings or any connections between internal and external spaces can be influenced by social perceptions. These elements, according to Thew and Sutcliffe [76] can be influenced by such things as individual emotions, society values and collective people's feelings about a design's benefits. Similarly, society views differently demographical changes. Differences in stakeholder interests sometimes mean that there are differing perceptions about which requirements are important and therefore of precedence. Understanding such intricate details in design decision making can be crucial in facilitating better delivery of project benefits [18].

\subsubsection{Health and Safety}

From site security and safety to hygienic design in healthcare facilities all through to acoustic compliance in individual built facilities, there is growing universal acceptance of health and safety as a requirement for compliance. Designing for hygiene can, for example, be a strict requirement for healthcare facilities [79]. Security is essential for times when sites as well as other facilities may or may not be in use [80]. Meanwhile, Malekitabar, Ardeshir [81] report that design processes have a role to play in combating site safety risks. There, however, appears to be contextual differences dependent on sociocultural, geopolitical, technological economic factors or otherwise in the perception of health and safety requirement factors. What stakeholders perceive as a safety benefit may differ from another group. Acoustic expectations as a requirement will not only differ depending on location or surroundings. Still, they may also be perceived differently as to how much they contribute to one's derived benefit. While critical for some designs, the flow or interconnection of spaces within the design may have a bearing on the hygienic requirement of a space or indeed how secure it is from physical or nonphysical security threats. This again is something that will likely not only differ in context but also perceived differently between and among different end-users.

\subsubsection{Technical}

Issues of constructability, design form, functional performance, collaboration and project processes are identified throughout this review as essential requirements for benefits realisation from a technical perspective [63,72]. Constructability for example that lends to the efficiency of processes in using up resources is interdependent with other technical requirements such project lead times, design form and functional performance or legal and compliance among others [82]. This literature review finds consistency in the position that traditional AEC practice and therefore, requirements management has been biased towards technical requirements in the definition and perceived benefits with over a quarter of articles focussed on this. Despite this bias, the technical requirements of design still influence much of what contributes to end-user perceived and derived benefits; although this appears to be at the expense of other requirements something that may obscure full understanding of the various complex interdependencies essential for full benefits realisation.

Similarly, although technical requirements have been dominant, collaboration has been the main emphasis of research in this requirements category with over half of the reviewed articles within it. There needs, therefore to be a broadening of consideration for such other technical factors as symbolism (design form) or functional design performance among others. The dominance of research into collaborative processes might also indicate biases into the sometimes apparent top-down AEC design practices meaning that technical teams have a propensity towards a prescriptive approach to design particularly when it comes to requirements management and how these are transformed into design requirements. Technical teams appear in practice to, for example, have control of how constructible a design is; defining such things as design decisions on form, materials and other specifications they adopt for design. Technology in construction is also increasingly influencing not 
only the course but the nature of project processes and ultimately design decision making as to the benefits delivery process; but also remains technically exclusive.

Similarly, how the design performs on compliance or aesthetics will influence benefit perceptions from end-users, but again these requirements are in the main controlled by technical stakeholders. Although demonstrably crucial in practice for its importance in such processes as modelling, [83]; there are limited studies on specification as a technical requirement for its interdependency with other requirements with only $3 \%$ of literature in this category devoted to it. As demonstrated by Pignataro, Lobaccaro [83], specifications can be a vital driver in harnessing wider benefits in projects.

\subsubsection{Lifecycle Performance}

During the benefits realisation cycle, stakeholders often find need where their spaces have to be serviced or maintained. This review identifies increasing interest in lifecycle performance of processes such for serviceability, accessibility [84,85] and maintainability [86]. In particular, there are opportunities in integrated processes and standardisation [85], Sustainable and continuing performance in product-service systems [84], data security in the IT [48] all issues making lifecycle performance an important requirement category during design decision making.

Maintainability of spaces is an increasing factor impacting on derived and perceived user and stakeholder benefits. This can mean issues relating to accessibility to the space or part of it to be maintained and how site planning facilitates this, for example. All these will ultimately translate into costs, be it for replacement or new changes. Design decision making relating to the use of technologies, materials, systems, among others, can play a significant role in influencing benefit delivery based on maintainability. Although lifecycle performance in these areas is widely accepted and acknowledged, there is a lack of clarity in the review as to exactly how this impacts on perceived benefits. Moreover, there is a growing acceptance that this understanding of lifecycle performance now needs to extend to the benefits of knowledge generation and sharing; such as in information interoperability, and usability across the project lifecycle [63].

\subsubsection{Occupancy}

Rodrigues and Freire [87] report on how low occupancy is taken into account when planning retrofits for lifecycle performance. In this review, it is evident that this is a requirements category that is explored least among all nine categories. Chiu, Lowe [88], however, report on opportunities for innovation and knowledge when occupancy is considered carefully as an essential requirement in design. Williams, Bouchlaghem [89], on the other hand, explores these opportunities in terms of collaborative processes that link many stakeholders in a manner that fosters and understands occupancy and its challenges.

Meanwhile, Hsueh, Lee [80] study the dangers of disused public buildings as a result of insufficient occupancy planning, particularly in design leading to insecurity. Changing consumer trends into experiential consumerism are now filtering through into AEC. This means that it is now just as much crucial that spaces meet the changing needs of occupants. Occupants' needs change over time include a change in levels or patterns-which may mean new additions or children moving out for a family home or company premises; income and status changes be it through new or lost opportunities and social status/aspiration to match these and other changing circumstances such environmental concerns. All these factors influence how stakeholders perceive and derive benefits concerning how a given space continually evolves to continue to meet changing family circumstances. The proliferation of garden cities is an example when occupancy factors were a significant consideration for design and benefits management processes.

\subsubsection{Geopolitics}

The influence of geopolitics in terms of political leadership has been highlighted by authors such as in how it influences decision making to impact on project value [31], how it influences contexts [76], 
its impact on contractual relationships in AEC processes [68] or rather how it can negatively impact on wider benefits [73] among others. Weaknesses in policy and legislation on the other are cited by Locatelli, Mariani [67] as a basis for proliferating corrupt project contexts. As a result, a lot of construction policy is now at the forefront of many local authorities and national political discussions be it in Europe or South America. Growing populations and changing family lifestyles are creating acute contextual needs, such as for affordable social housing or major infrastructure [68]. Geopolitical factors are, therefore, increasingly influencing benefit perceptions on the one hand and benefits management processes on the other; be it through prescriptive legislation and compliance regimes or merely changing policy from one position to another.

\subsubsection{Environment}

The increasing focus on the environmental performance of designs now extends to such vital aspects as requirements for adaptability $[90,91]$. Buildings often now require refurbishment, including bringing any upgrades to say the aesthetic and functional performance of a building [90]. The buildings may also come under the need for rehabilitation or some modernisation sometimes with some extension work or indeed any retrofit. This is similar to increasing need for designs to reflect on materials use [62]; and lifecycle costs [92,93]; as well as issues relating to the physical management of the immediate building's environment as well its wider one [73].

These requirements are being forced through by the increasing awareness of the world around which has ignited a new demand from AEC towards environmentally friendly practices. How environmentally friendly a design is now and in the future is likely to influence benefits perceptions and delivery. This means focusing on design areas such as energy performance, physical management, materials use, lifecycle costs and adaptability of design. This also extends to such simple considerations for design specification as to the appropriate glazing design that addresses seasonal changes in solar gain/loss, environmentally friendly materials and adaptability of designs in the face of increasing need for environmental performance.

\subsubsection{Governance}

Locatelli, Mariani [67] and Wolter and Meinel [94] are among a growing number of authors to explore the essential dynamics of project governance, stakeholder management and project contexts. Of particular notice is the limited research coverage of project context among them that can, however, be a vital requirement for the delivery of contextual project benefits. Carrizo, Dieste [95], for example, observe that the effectiveness of the requirements elicitation process is dependent on the context-basically the structure of the project context. Chakraborty [73] draws on the utilitarian biases among Japanese policymakers in the continuing proliferation of dam project despite their impact on the environment. On the other hand, however, van de Kar and Den Hengst [96] draw on the importance of participatory and collaborative processes in drawing out any of these essential contextual nuances that may be critical to benefits perceptions.

Additionally and while acknowledging challenges that may come with wider stakeholder involvement, Knauss, Yussuf [97] point to opportunities for innovation and stakeholder association and ownership of any benefits. This shared stakeholder understanding that is important in helping meet today's diverse project stakeholder expectations is what has been referred to as value co-creation [98].

From a benefits realisation perspective, project governance is central to the delivery of intended benefits through advocacy for organisational change as a critical element to the successful delivery of projects. Increasingly, literature is adding to the knowledge that project governance does impact the success of projects. As a result, how projects are governed, and knowledge is shared and governed play an essential role for stakeholders in the perception of benefits be it through collaborative and integrated design practice or otherwise. Research needs to move, however, to explore the intricacies of governance requirements and draw out their clear implications on projects' benefits. 


\section{Conclusions}

In exploring the state of the art in requirements management and benefits realisation, the review reveals a gap in research in bridging the two concepts; and as a result, highlights several potential areas for new knowledge from the results. Firstly, it is seen that benefits realisation as a concept is receiving limited focus in research, yet its practices and concepts can be key to project success. It creates a bridge between many requirements in terms of their categorisations and understanding including that relating to the emerging concepts of knowledge governance, user benefits relating to individual and broader socio-cultural, economic and geopolitical societal goals among others. Moreover, exploration of benefits realisation concept at intermediate benefits level (see [99]; merits further understanding something that would contribute to the role of FED in generating wider project benefits. These positions alone can contribute to new understanding among project delivery practice in anchoring organisational goals to user benefits and building understanding going forwards in the project lifecycle as to how these benefits are continually being realised.

Secondly, this research has highlighted a gap in understanding and practice of requirements management, particularly in an FED perspective with limited new research to support broader adoption and understanding of the various essential project requirements. Although the understanding of requirements management as an essential link to the delivery of benefits, particularly in FED processes that continue to evolve, it is doing so disjointedly and even less for some requirements understanding. Some requirements such as strategic value and collaboration and project governance have received a great deal of attention in research though this has been at the expense of others in terms of their conceptual understanding.

Regarding requirements categorisations, they are an important element in defining project requirements and potentially a basis for understanding interdependences among them. However, more understanding of this influencing role is needed. For example, technical, economics, governance and environmental requirements categorisations have understandably dominated current bodies of research. This again has been at the expense of such other categorisations such as occupancy whose constituent requirements such as occupancy levels and patterns appear central to today's design decision making particularly with the increasing adaptability expectation from designs. Globalisations means that millions around the world are delivered from poverty to middle or working class and therefore places emphasis on the understanding of such requirements as mobility, social or financial status and aspirations of many project stakeholders.

Thirdly, the change and control model presented in this review reveals potential interfaces between requirements management and benefits realisation. There are demonstrable and notable overlaps in the separate bodies of research, but these remain thin and mostly peripheral to the main findings in this research. In practice, this means a potential new understanding of the influencing role of requirements on benefits realisation. The authors have sought to bring out this understanding and bridge these various gaps in drawing out any convergences in an attempt to harness any overlaps. This effort has been to map the main factors across a range of bodies of research and attempting to recast these in the perspective of FED processes in nine main categories. More understanding is, however, needed to draw out any impact of requirements dynamics and interdependences on benefits realisation, particularly in the dynamic FED stages of projects.

This systematic literature review while making an essential contribution to new understanding of requirements management as a vital driver for benefits delivery in FED, therefore, acknowledges new potential research paths as follows:

- The research has drawn to nine specific focus factors as broad categorisations for not only faster identification but also for contextual modelling. This categorisation nonetheless should in no way constrain any emergent categorisations following the evolution of discussion. This means any future emergent positions contributing to these categorisations are welcome. 
- Similarly, the 33 factors identified within these broad categorisations serve as no constraint to any future broadening or reconfiguration in any order but instead merely serve as a basis for new understanding and discussion. It is accepted that different research positions and modelling may undoubtedly reconfigure the factors in ways best suitable for them and therefore herein should again serve merely as a basis for further discussion. Moreover, it is vital to highlight the importance of any project or process-specific interdependencies between these factors that can be vital to the realisation of the specific project benefits that this research has not attempted to discern. This represents a future area of significant and active research to draw on the context-specific nature of intermediate and broader project benefits, particularly during FED.

- The study has laboured to draw the vital link between benefits realisation in the perspective of requirements management in FED. It is noticeable that some focus factors such as environmental performance and governance, among others on the one hand; and factors such as collaboration, strategic value and constructability are widely discussed in the literature. However, there appears a limited discussion on their crucial link and contribution to intermediate and wider project benefits realisation. For example, collaboration, strategic value and stakeholder management represent a vital link for requirements management and benefits realisation, but this has to be to recast in an FED perspective. Limited research, however, appears to do this. Moreover, there is no evidence at all that other important factors in benefits perceptions such as family and social and geopolitics are considered within the separate discussions of the key conceptualisations, and certainly not in a unified position. New research understanding is needed in the perspective of FED to help explicate these essential parameters.

- Finally, benefits realisation relies on derived benefits being measurable of benefits along the process of use. However, there has not been any research into any quantitative approaches to support quantitative processes in the practice of benefits realisation. For example, current design discourse uses explanatory and rational approaches to draw on any interdependencies among design factors, something that may be inadequate for the increasingly complex design environment. New quantitative modelling approaches are needed to cope with this increasing complexity to better reflect and capture the essential interdependencies in informing design decision making. New research is, for example, needed into modelling the complex dynamics in user needs changes during and after design, so projects can stay relevant and in step with user needs continually.

This study has sought to explore the state of the art of FED research and practice regarding the key conceptualisations of benefits realisation and requirements management. In contributing to this body of research and in highlighting gaps in current understanding, this research acknowledges and accepts some limitations borne upon it. First is the limitation relating to the pool of literature on the one hand and or the extensive keywords in various bodies of knowledge used in drawing to the results. Many other databases undoubtedly have explored these interesting concepts in various forums and languages though these have been excluded for analysis while others that may not have been available at the point of analysis may since have. Exclusion also extended to conference articles something that does not in any way imply that concepts covered in there are unworthy for consideration in this research. The results, therefore, are devoid of this excluded body of research. Despite these and other inadvertent limitations, it is the position of this research that it draws new understanding in attempting to unify the key conceptualisations and hence form a basis for new knowledge and discussion for practice and research engaged in FED processes and benefits realisation.

Author Contributions: Conceptualization, J.S., M.K.; methodology, software J.S.; validation, J.S., M.K. and P.T.; formal analysis, J.S.; resources, M.K.; data curation, J.S.; writing—original draft preparation, J.S., M.K.; writing-review and editing, J.S., M.K.; visualization, J.S.; supervision, M.K., P.T.; project administration, M.K., P.T.; All authors have read and agreed to the published version of the manuscript.

Funding: This research received no external funding.

Conflicts of Interest: The authors declare no conflict of interest. 


\section{Appendix A}

Table A1. Selection of Case Studies in Construction.

\begin{tabular}{|c|c|c|c|}
\hline Author & Factors & Requirements Category & Study Brief \\
\hline Boton [100] & constructability, collaboration & Technical & \\
\hline Śladowski [101] & $\begin{array}{l}\text { Stakeholder Management, } \\
\text { Project Governance }\end{array}$ & Governance & $\begin{array}{l}\text { A study to identify key the means of production employed to measure of } \\
\text { performance of projects modelled using a metanetwork; using a modified } \\
\text { performance measure for the purposes of identifying key agents, knowledge and } \\
\text { resources of a planned project }\end{array}$ \\
\hline $\mathrm{Hu}$ [102] & $\begin{array}{l}\text { Adaptability, Strategic Value, } \\
\text { Project Context }\end{array}$ & $\begin{array}{l}\text { Environment, Economics, } \\
\text { Governance }\end{array}$ & $\begin{array}{c}\text { dynamic life cycle assessment (LCA) framework that includes temporal and users' } \\
\text { value choice factors }\end{array}$ \\
\hline Volk, Luu [103] & Specification & Technical & $\begin{array}{l}\text { Development of a system for building information acquisition, 3D reconstruction, } \\
\text { object detection, building inventory generation and optimized project planning }\end{array}$ \\
\hline Smyth, Lecoeuvre [31] & $\begin{array}{l}\text { Project Governance, Strategic value, } \\
\text { Political Leadership, Policy, Culture }\end{array}$ & $\begin{array}{l}\text { Governance, Economics, } \\
\text { Geopolitics, Sociocultural }\end{array}$ & $\begin{array}{l}\text { A study on the application of benefits realisation concepts to the Hinckley Point C } \\
\text { Nuclear Station in the U.K. }\end{array}$ \\
\hline Brioso, Humero [104] & Strategic Value, Policy & Economics, Geopolitics & $\begin{array}{l}\text { a value-generation framework for municipalities through the adaptation of the } \\
\text { Lean Project Delivery System }\end{array}$ \\
\hline Pal, Takano [105] & Energy Performance & Environmental & $\begin{array}{l}\text { A study into life cycle simulation-based optimization of buildings with a focus on } \\
\text { the operational carbon footprint (OCF) and embodied carbon footprint (ECF) }\end{array}$ \\
\hline Shen, Tang [106] & $\begin{array}{l}\text { Life Cycle Costs, Collaboration, } \\
\text { Compliance, }\end{array}$ & Environment, Technical & $\begin{array}{c}\text { An investigation into the critical success factors of Green Buildings and their } \\
\text { relationships with GB certification }\end{array}$ \\
\hline Roux, Schalbart [107] & $\begin{array}{l}\text { Life cycle costs, Energy Performance, } \\
\text { Strategic Value }\end{array}$ & Environment, Economics & $\begin{array}{c}\text { Evaluating life cycle impacts of buildings, integrating climate change and } \\
\text { evolution of the energy mix on the long term }\end{array}$ \\
\hline Kemp and Scholl [108] & Community, Policy & Social, Geopolitics & $\begin{array}{l}\text { A study into the role of urban experiments for local planning processes through a } \\
\text { case-based analysis of the city lab of Maastricht }\end{array}$ \\
\hline $\begin{array}{l}\text { Samset and } \\
\text { Volden [46] }\end{array}$ & $\begin{array}{l}\text { Project Context, Governance, } \\
\text { Stakeholder management, } \\
\text { Political Leadership }\end{array}$ & $\begin{array}{l}\text { Governance, Technical, } \\
\text { Geopolitics }\end{array}$ & $\begin{array}{l}\text { A study of front-end management and governance of major public investment } \\
\text { projects in Norway }\end{array}$ \\
\hline Buyle, Audenaert [70] & $\begin{array}{l}\text { Construction Costs, Project Costs, } \\
\text { Strategic Value, Energy Performance, } \\
\text { Life Cycle costs, Policy, Project Context }\end{array}$ & $\begin{array}{l}\text { Environment, Economics, } \\
\text { Geopolitics, Governance }\end{array}$ & $\begin{array}{c}\text { An investigation into scenarios to improve the environmental profile of new } \\
\text { buildings in the Flemish/Belgian context }\end{array}$ \\
\hline $\begin{array}{l}\text { Russell-Smith and } \\
\text { Lepech [92] }\end{array}$ & $\begin{array}{l}\text { collaboration, Life cycle costs, } \\
\text { Stakeholder Management, } \\
\text { Project Costs }\end{array}$ & $\begin{array}{l}\text { Technical, Environment, } \\
\text { Governance, Economics }\end{array}$ & $\begin{array}{l}\text { a method to measure and manage the cradle-to-gate life cycle environmental } \\
\text { impacts by linking environmental targets with modern construction management } \\
\text { methods, to enable buildings to meet sustainable target values (STV) }\end{array}$ \\
\hline
\end{tabular}


Table A1. Cont.

\begin{tabular}{|c|c|c|c|}
\hline Author & Factors & Requirements Category & Study Brief \\
\hline $\begin{array}{l}\text { Shackleton, } \\
\text { Hebinck [71] }\end{array}$ & $\begin{array}{l}\text { Strategic Value, Community, Policy, } \\
\text { Political Leadership, Collaboration, } \\
\quad \text { Project Governance }\end{array}$ & $\begin{array}{l}\text { Technical, Governance, } \\
\text { Economics, Geopolitics }\end{array}$ & $\begin{array}{l}\text { A study into policy initiatives for urban forestry and greening including the } \\
\text { maintenance, use and appreciation of trees on private homesteads of residents of } \\
\text { new and older low-income suburbs as well as informal housing areas }\end{array}$ \\
\hline $\begin{array}{l}\text { Pignataro, } \\
\text { Lobaccaro [83] }\end{array}$ & $\begin{array}{c}\text { Functional Design, } \\
\text { Specification, Accessibility }\end{array}$ & $\begin{array}{l}\text { Technical, Life Cycle } \\
\text { Performance }\end{array}$ & Sustainable Design \\
\hline Shen, Zhang [109] & $\begin{array}{l}\text { Acoustics, Collaboration, Life Cycle } \\
\text { Costs, Serviceability }\end{array}$ & $\begin{array}{l}\text { Health and Safety, } \\
\text { technical, Life Cycle } \\
\text { Performance }\end{array}$ & $\begin{array}{c}\text { An Evaluation of User Pre-Occupancy to enhance the designer-client } \\
\text { communication by applying building information modelling, user activity } \\
\text { simulation, and requirement management techniques }\end{array}$ \\
\hline Lin [110] & Strategic Value & Economics & $\begin{array}{c}\text { A study into tracking and management of interface events by using } \\
\text { Network-based Interface Maps (NBIM) }\end{array}$ \\
\hline Himpe, Trappers [93] & $\begin{array}{l}\text { Energy Performance, Life Cycle Costs, } \\
\text { Serviceability }\end{array}$ & $\begin{array}{l}\text { Environmental, } \\
\text { Life Cycle Performance }\end{array}$ & $\begin{array}{c}\text { Examining the life cycle Energy Performance of a Belgian zero-energy } \\
\text { reference house }\end{array}$ \\
\hline Lu and Hao [111] & Collaboration, Project Context & & Technical, Governance \\
\hline Rezgui, Beach [112] & Stakeholder Management, Compliance & Governance, Technical & $\begin{array}{c}\text { a governance approach for managing multi-actor, multi-discipline, and total } \\
\text { lifecycle data, }\end{array}$ \\
\hline Ghosh, Amaya [42] & $\begin{array}{l}\text { Project Governance, Collaboration, } \\
\text { Strategic Value }\end{array}$ & Governance, Economics & $\begin{array}{l}\text { A study to identify problem areas of knowledge creation and management and } \\
\text { how these can be aligned to corporate and project objectives }\end{array}$ \\
\hline $\begin{array}{c}\text { Abduh, } \\
\text { Soemardi [113] }\end{array}$ & Strategic Value, Project Context & Economics, Governance & $\begin{array}{l}\text { Investigating the cost structure of construction supply chains in Indonesia and } \\
\text { factors that could influence it }\end{array}$ \\
\hline Liu, Hsueh [114] & Energy Performance & Environmental & Decision making \\
\hline Chakraborty [73] & $\begin{array}{l}\text { Political Leadership, Project Context, } \\
\text { Strategic Value, Physical Performance }\end{array}$ & $\begin{array}{l}\text { Geopolitics, Economics, } \\
\text { Environment }\end{array}$ & $\begin{array}{l}\text { A Study into the } 1997 \text { River Law, examining some most contentious river valley } \\
\text { projects, and concludes that a myth of vulnerability to flooding, short-sightedness } \\
\text { of river engineers, and bureaucratic inertia combine to place basin governance in a } \\
\text { time warp }\end{array}$ \\
\hline Gasafi and Weil [115] & Project Processes & Technical & \\
\hline $\begin{array}{l}\text { Chandra and } \\
\text { Loosemore [116] }\end{array}$ & Collaboration, Project Governance & & Technical, Governance \\
\hline Singh, Gu [117] & constructability, collaboration & & Governance, Technical \\
\hline Yeung, Chan [118] & collaboration, strategic value & Technical, Economics & $\begin{array}{l}\text { A study into Partnering Performance for seven weighted Key Performance } \\
\text { Indicators (KPIs), to support to measurement, monitoring, improvement, } \\
\text { and benchmarking of the partnering performance of construction projects }\end{array}$ \\
\hline
\end{tabular}




\section{Appendix B}

Table A2. Reviewed Studies by year, methodology, sector and requirements factors identified.

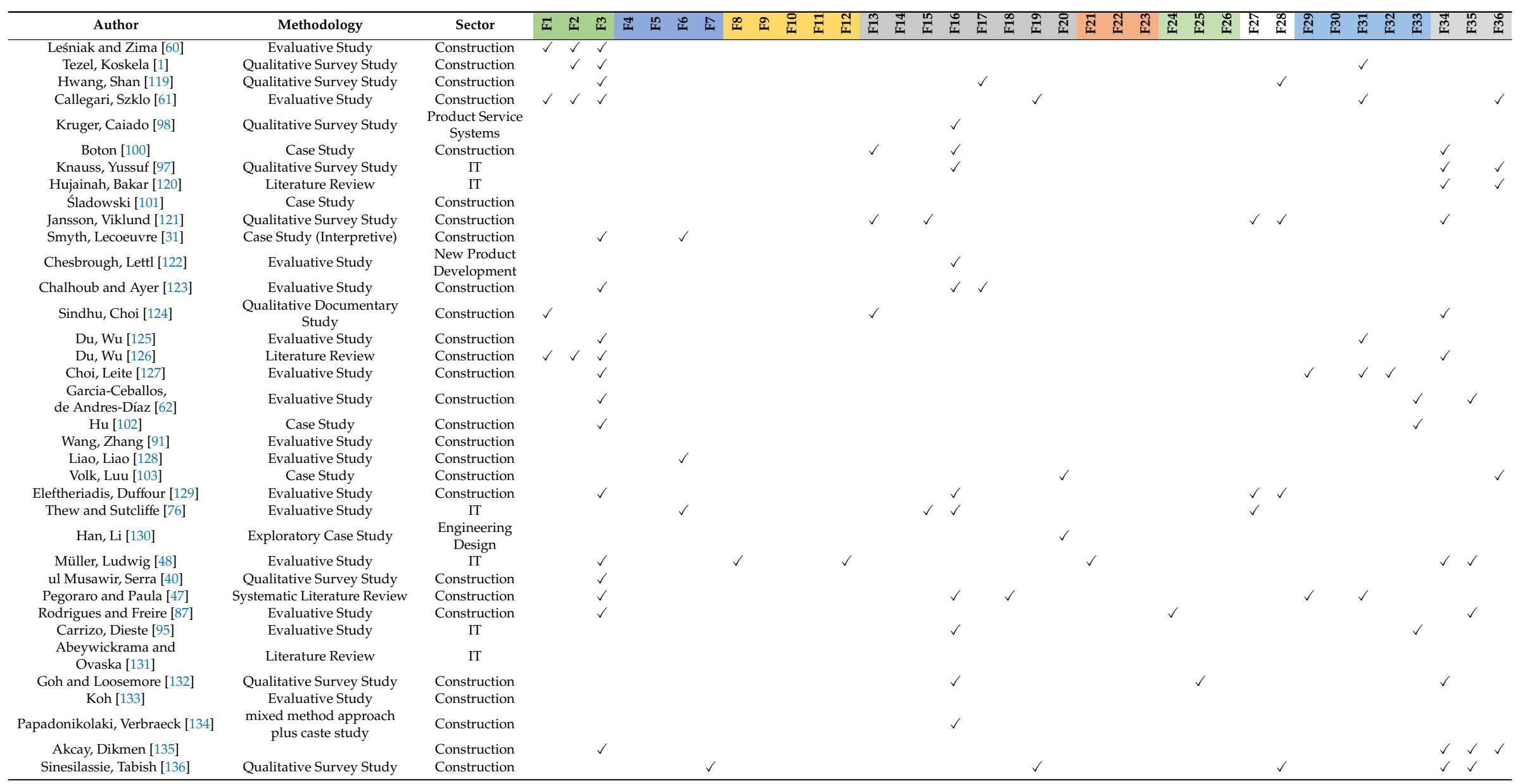


Table A2. Cont.

\begin{tabular}{|c|c|c|c|c|c|c|c|c|c|c|c|c|c|c|c|c|c|c|c|c|c|c|c|c|c|c|c|c|c|c|}
\hline Author & Methodology & Sector & $\bar{I}$ & 논 & 象 & 武 点 & 占 & 缶 & $\infty$ & is & 至 & I & 兽 & $\frac{10}{E}$ & 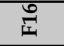 & 至 & $\stackrel{\infty}{a}$ & 可 & $\bar{x}$ & స్ & 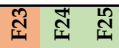 & $\begin{array}{ll}\sqrt{2} & \text { a } \\
\end{array}$ & đi & तิ & 产 & $\bar{P}$ & 兽 & है & $\stackrel{0}{10}$ & 总 \\
\hline $\begin{array}{l}\text { Locatelli, Mariani [67] } \\
\text { Lin, Zeng [137] }\end{array}$ & $\begin{array}{c}\text { Evaluative Case Study } \\
\text { Oualitative Survev Study }\end{array}$ & $\begin{array}{l}\text { Construction } \\
\text { Construction }\end{array}$ & & $\checkmark$ & $\checkmark$ & & $\begin{array}{l}\checkmark \\
\checkmark\end{array}$ & & & & & & & & t & & $\checkmark$ & $\checkmark$ & & & & & & & & $\checkmark$ & s & $\checkmark$ & & $\begin{array}{l}\checkmark \\
\checkmark\end{array}$ \\
\hline Cavka, Staub-French [63] & Qualitative Survey Study & Construction & & & $\checkmark$ & & & & $\checkmark$ & & & $\checkmark$ & $\checkmark$ & $\checkmark$ & $\checkmark$ & & $\checkmark$ & & $\checkmark$ & $\checkmark$ & & & & $\checkmark$ & & & & & & \\
\hline Sleiman, Hempel [138] & Evaluative Study & Construction & & & & & $\checkmark$ & & & & & & & & & & & & & & & & & & & & & $\checkmark$ & & \\
\hline Cardenas, Voordijk [139] & Evaluative Study & Construction & & & $\checkmark$ & & & & & & & & & & $\checkmark$ & & & & & & & & & & & & & $\checkmark$ & & \\
\hline Wiese, Ré [140] & Evaluative Study & IT & & & & & & & & & & & & & $\checkmark$ & & & & & & & & & & & & & & $\checkmark$ & \\
\hline Hastie, Sutrisna [141] & Case Study, Survey & Construction & & & & & & & & & & & $\checkmark$ & & $\checkmark$ & & & & & & & & $\checkmark$ & $\checkmark$ & & & & & $\checkmark$ & \\
\hline Sanderson and Winch [142] & Evaluative Study & Construction & & & & & & & & & & & & & $\checkmark$ & & & & & & & & & & & & & $\checkmark$ & & $\checkmark$ \\
\hline Mok, Shen [56] & Case Study & Construction & & & $\checkmark$ & & $\checkmark$ & & & & & & & $\checkmark$ & $\checkmark$ & & $\checkmark$ & & & & & & $\checkmark$ & & & & & $\checkmark$ & & $\checkmark$ \\
\hline Samset [143] & Literature Review & Construction & & & $\checkmark$ & & & & & & & & & & & & & & & & & & & & & $\checkmark$ & & & & \\
\hline Eckart, McPhee [144] & Literature Review & Construction & & & & & $\checkmark$ & & & & & & & $\checkmark$ & & & & & & & & & & & & & & & & \\
\hline Saoud, Omran [145] & Case Study, Survey & Construction & & & & & & & & & & & & & $\checkmark$ & & & & & & & & & $\checkmark$ & & & & & & \\
\hline Clarke, Gleeson [146] & Evaluative Study & Construction & & & & & & & & & & & & & & $\checkmark$ & & & & & & & & & & & & & & \\
\hline Oraee, Hosseini [147] & Systematic Literature Review & Construction & & & & & & & & & & & & & $\checkmark$ & & & & & & & $\checkmark$ & & & & $\checkmark$ & & & & \\
\hline Vernet and Coste [77] & Evaluative Study & Construction & & & $\checkmark$ & & $\checkmark$ & & & & & & & & & & & & & & & & & & & & & $\checkmark$ & & \\
\hline $\begin{array}{l}\text { Buchmann and } \\
\text { Karagiannis [148] }\end{array}$ & Evaluative Study & IT & & & $\checkmark$ & & & & & & & & & & $\checkmark$ & & $\checkmark$ & & & & & & & & & & & & & \\
\hline Shin, Jeong [149] & Evaluative Study & Construction & & & $\checkmark$ & & & & & & & $\checkmark$ & & & $\checkmark$ & & & & & & & & & & & & & & & $\checkmark$ \\
\hline Revellino and Mouritsen [150] & Evaluative Study & Construction & & & & & & & & & & & & & $\checkmark$ & & & & & & & & $\checkmark$ & & & & & & & \\
\hline Rowlinson [151] & Literature Review & Construction & & & & & & & & & & & & & & $\checkmark$ & & & & & & & & $\checkmark$ & & & & & & \\
\hline Pal, Takano [105] & Case Study & Construction & & & & & & & & & & & & & & & & & & & & & & $\checkmark$ & & & $\checkmark$ & $\checkmark$ & & $\checkmark$ \\
\hline Sousa-Zomer and Miguel [84] & $\begin{array}{l}\text { Qualitative Documentary } \\
\text { Study }\end{array}$ & $\begin{array}{l}\text { Product Service } \\
\text { Systems }\end{array}$ & & & & $\checkmark$ & & & $\checkmark$ & & & & & & & & & & & $\checkmark v$ & & & & & & & & & & \\
\hline Heikkilä, Paasivaara [152] & Qualitative Survey Study & IT & & & $\checkmark$ & & & & & & & & & & & & & & & & & & & & & $\checkmark$ & & $\checkmark$ & & \\
\hline Galle, De Temmerman [153] & Evaluative Study & Construction & & & $\checkmark$ & & & & & & & & & & & & & & & & & & & & & $\checkmark$ & & & & \\
\hline Shen, Tang $[106]$ & Case Study & Construction & & & & & & & & & & & & $\checkmark$ & $\checkmark$ & & & & & & & & $\checkmark$ & 1 & & & & & & \\
\hline Brioso, Humero [104] & Action Research & Construction & & & $\checkmark$ & & & & & & & & & & & & & & & & & & & & $\checkmark$ & $\checkmark$ & & & & \\
\hline Dias, Chandratilake [154] & & Construction & & & & & & & & & & & & & & & & & & & & & & & & & & & & \\
\hline Kpamma, Adjei-Kumi [155] & Evaluative Study & Construction & & & & & & & & & & & & & $\checkmark$ & $\checkmark$ & & & & & & & & & & $\checkmark$ & & & & \\
\hline Hollberg and Ruth [156] & Quantitative Model analysis & Construction & & & & & & & & & & & & & & & & & & & & & & & & & $\checkmark$ & & & \\
\hline del Caño, Pilar de la Cruz [157] & Evaluative Study & Construction & & & & & & & & & & & & $\checkmark$ & & & & & & & & & & & & & & $\checkmark$ & & $\checkmark$ \\
\hline Haddadi, Johansen [158] & Literature Review & Construction & & & & & & & & & & & & & & & & & & & & & & & & & & & & $\checkmark$ \\
\hline Davies and Brady [159] & Evaluative Study & Construction & & & $\checkmark$ & & & & & & & & & & $\checkmark$ & & & & & & & & & & & & & & $\checkmark$ & \\
\hline Immonen, Ovaska [160] & Evaluative Study & IT & & & $\checkmark$ & & & & & & & & & & $\checkmark$ & & & & & & & & & $\checkmark$ & & & & & & \\
\hline Nielsen, Jensen [161] & Evaluative Study & Construction & & & & & & & & & & & & $\checkmark$ & & $\checkmark$ & & & & & & & & & & & & $\checkmark$ & $\checkmark$ & \\
\hline Jussila, Mainela [162] & Case Study & Construction & & & $\checkmark$ & & & & & & & & & & $\checkmark$ & & & & & & & & & & & & & & & \\
\hline Dave, Kubler [163] & Design Science Research & Construction & & & & & & & & & & & & & $\checkmark$ & & & & & & & & & $\checkmark$ & & $\checkmark$ & & & & \\
\hline Roux, Schalbart [107] & Case Study & Construction & & & $\checkmark$ & & & & & & & & & & & & & & & & & & $\checkmark$ & $\checkmark$ & & $\checkmark$ & & & & \\
\hline Delmastro, Mutani [164] & Evaluative Study & Construction & & & & & & & & & & & & & & & & & & & & & $\checkmark$ & 1 & & & & & & \\
\hline Kemp and Scholl [108] & Case Study & Construction & & & & & $\checkmark$ & & & & & & & & & & & & & & & & & & & & & & & \\
\hline Addison, Campbell Jenkins [165] & Case Study & Health & & & $\checkmark$ & $\checkmark$ & $\checkmark$ & & & & $\checkmark$ & & & & & & & & & & & & & & & & & & & \\
\hline Bacciotti, Borgianni [166] & $\begin{array}{l}\text { Qualitative Documentary } \\
\text { Study }\end{array}$ & $\begin{array}{l}\text { New Product } \\
\text { Development }\end{array}$ & & & $\checkmark$ & & & & & & & & & & & & & & & & & & & & & & & & & \\
\hline Malekitabar, Ardeshir [81] & $\begin{array}{l}\text { Qualitative Documentary } \\
\text { Study }\end{array}$ & Construction & & & & & & & $\checkmark$ & & & $\checkmark$ & & & & & & & & & & & & & & & & $\checkmark$ & & $\checkmark$ \\
\hline $\begin{array}{l}\text { Wei, Liu [167] } \\
\text { Palm and Reindl [69] }\end{array}$ & $\begin{array}{l}\text { Evaluative Study } \\
\text { Evaluative Study }\end{array}$ & $\begin{array}{l}\text { Construction } \\
\text { Construction }\end{array}$ & & & $\begin{array}{l}\checkmark \\
\checkmark\end{array}$ & & $\checkmark$ & & & & & & & & & & & & $\checkmark$ & & & & $\checkmark$ & $\checkmark$ & & $\checkmark$ & $\checkmark$ & & $\checkmark$ & $\checkmark$ \\
\hline
\end{tabular}


Table A2. Cont.

\begin{tabular}{|c|c|c|c|c|c|c|c|c|c|c|c|c|c|c|c|c|c|c|c|c|c|c|c|c|c|c|c|c|}
\hline Author & Methodology & Sector & 㞋 & \pm & P & 些 & 电 & 至 & 冓 & 垔 & 至 & 鄫恶 & $\frac{10}{3}$ & 里 & $\overrightarrow{A^{2}}$ & $\stackrel{\infty}{2}$ & 올 त्ञ & $\sqrt{4} \pi$ & त्ञ & 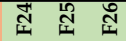 & 产 & i & क्षे है & $\vec{p}$ & 赵 & 䗱 & 寜 & 兽 \\
\hline $\begin{array}{l}\text { Samset and Volden [46] } \\
\text { Ferreira, Almeida [168] }\end{array}$ & $\begin{array}{c}\text { Case Study } \\
\text { Evaluative Study }\end{array}$ & $\begin{array}{l}\text { Construction } \\
\text { Construction }\end{array}$ & & & $\checkmark$ & & & & & & & & & $\checkmark$ & & & & & & & $\checkmark$ & $\checkmark v$ & $\checkmark$ & $\checkmark$ & & & $\checkmark$ & \\
\hline $\begin{array}{l}\text { Ferreira, Almeida [168] } \\
\text { Surlan, Cekic [78] }\end{array}$ & $\begin{array}{l}\text { Evaluative Study } \\
\text { Qualitative Survey Study }\end{array}$ & $\begin{array}{l}\text { Construction } \\
\text { Construction }\end{array}$ & & & $\checkmark$ & & & $\checkmark$ & & & & & & $\checkmark$ & & & & & & & & & & & & $\checkmark$ & $\checkmark$ & \\
\hline Müller, Zhai [169] & Qualitative Survey Study & Construction & & & $\checkmark$ & & & & & & & & & & & & & & & & & & & & & & & \\
\hline Dias, Cabral [170] & Case Study & $\begin{array}{l}\text { Engineering } \\
\text { Design }\end{array}$ & & & $\checkmark$ & & & & & & & & & $\checkmark$ & & & & & & & $\checkmark$ & $\checkmark$ & & & & & & $\checkmark$ \\
\hline $\begin{array}{c}\text { Osei-Kyei and Chan [68] } \\
\text { Bayram, Ocal [171] }\end{array}$ & $\begin{array}{l}\text { Evaluative Study } \\
\text { Evaluative Study }\end{array}$ & $\begin{array}{l}\text { Construction } \\
\text { Construction }\end{array}$ & $\checkmark$ & $\checkmark$ & $\checkmark$ & & & & & & & & & & $\checkmark$ & & & & & $\checkmark$ & & & & & & & & \\
\hline Ledoux, Teissandier [172] & Evaluative Study & $\begin{array}{l}\text { Engineering } \\
\text { Design }\end{array}$ & & & $\checkmark$ & & & & & & & & & $\checkmark$ & & $\checkmark$ & & & & & & & & & & $\checkmark$ & & \\
\hline Hoła, Sawicki [173] & Evaluative Study & Construction & & & $\checkmark$ & & & & & & & & & & & & & & & & & $\checkmark$ & & $\checkmark$ & & $\checkmark$ & & \\
\hline Vezzoli, Ceschin [65] & Evaluative Study & $\begin{array}{l}\text { Product Service } \\
\text { Systems }\end{array}$ & & & $\checkmark$ & & $\checkmark$ & & & & $\checkmark$ & & & $\checkmark$ & $\checkmark$ & & & & & $\checkmark$ & & & & & & & & \\
\hline Plewa, Sweeney [174] & Evaluative Study & $\begin{array}{l}\text { New Product } \\
\text { Development }\end{array}$ & & & $\checkmark$ & & & & & & & & & & & & & & & & & & & & $\checkmark$ & & & \\
\hline Lung, Balasubramaniam [175] & Case Study & IT & & & $\checkmark$ & & & & & & & & & & & & & & & & & & & & & & & \\
\hline Dagan and Isaac [176] & Action Research & Construction & & & & & & & $\checkmark$ & & & & & & $\checkmark$ & & & & & & & & & & $\checkmark$ & $\checkmark$ & & \\
\hline Koh, Förg [177] & Case Study & $\begin{array}{l}\text { Engineering } \\
\text { Design }\end{array}$ & & & & & & & & & & & & & & & & & & & & & & & & & & \\
\hline Li, Arditi [178] & Literature Review & Construction & $\checkmark$ & $\checkmark$ & $\checkmark$ & & & & & & & & & & & & & & & & & & & & & & & \\
\hline Inayat, Salim [13] & Case Study & IT & & & & & & $\checkmark$ & & & & & & $\checkmark$ & & & & & & & & $\checkmark$ & $\checkmark$ & $\checkmark$ & & & $\checkmark$ & \\
\hline $\begin{array}{l}\text { Buyle, Audenaert [70] } \\
\text { Singhaputtangkul and Low [179] }\end{array}$ & Case Study & Construction & $\checkmark$ & $\checkmark$ & $\checkmark$ & & & & & & & & & & & & & & & & & & & & & & & \\
\hline $\begin{array}{l}\text { Singhaputtangkul and Low [179] } \\
\text { Almeida, Sousa [85] }\end{array}$ & Case Study & Construction & & & 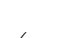 & & & & & & & $\checkmark$ & & & & & & & & & & & & & & & & 1 \\
\hline $\begin{array}{l}\text { Almeida, Sousa [85] } \\
\text { Russell-Smith and Lepech [92] }\end{array}$ & $\begin{array}{l}\text { Evaluative Study } \\
\text { Case Study }\end{array}$ & $\begin{array}{l}\text { Construction } \\
\text { Construction }\end{array}$ & & $\checkmark$ & $\checkmark$ & & & & & & $\checkmark$ & & & $\begin{array}{l}\checkmark \\
\checkmark\end{array}$ & $\checkmark$ & & & $\checkmark$ & & & & & & $\checkmark$ & & & & $\checkmark$ \\
\hline Serra and Kunc [99] & Survey & IT & & & $\checkmark$ & & & & & & & & & & & & & & & & & & & & & & & \\
\hline Jung, Moon [180] & Evaluative Study & Construction & & & $\checkmark$ & & & & & & & & & & & & & & & & & & $\checkmark$ & $\checkmark$ & & & & \\
\hline Lu, Wang [181] & Literature Review & Construction & & & $\checkmark$ & & & & & & & & & & & & & & & & $\checkmark$ & $\checkmark$ & & & & $\checkmark$ & & \\
\hline Shackleton, Hebinck [71] & Case Study & Construction & & & $\checkmark$ & & $\checkmark$ & & & & & & & $\checkmark$ & & & & & & & & 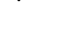 & & & & & & \\
\hline Too and Weaver [182] & Literature Review & Construction & & & $\checkmark$ & & & & & & & & & $\checkmark$ & & & & & & & & $\checkmark$ & & & & & $\checkmark$ & $\checkmark$ \\
\hline Locatelli, Mancini [52] & Literature Review & Construction & & & & & & & & & & & & & & & & & & & & & & & & & & \\
\hline Tserng, Ho [183] & Action Research & Construction & & & & & & & & & & & & & & $\checkmark$ & $\checkmark$ & & & & & & & & & & & $\checkmark$ \\
\hline Kw Wong, Kumaraswamy [184] & Case Study & Construction & & & $\checkmark$ & & & & & & & & & $\checkmark$ & & & & & $\checkmark$ & & & & $\checkmark$ & $\checkmark$ & & & & \\
\hline Chiu, Lowe [88] & Evaluative Study & Construction & & & $\checkmark$ & & & & & & & & & & & & & & & $\checkmark$ & & & & & & & & \\
\hline Pignataro, Lobaccaro [83] & Case Study & Construction & & & & & & & & & & & & & & $\checkmark$ & $\checkmark$ & $\checkmark$ & & & & & $\checkmark$ & & & & & \\
\hline Shaikh, Nor [185] & Literature Review & Construction & & & & & & & & $\checkmark$ & & & & & & & & & & & & & & & & $\checkmark$ & & \\
\hline Pemsel, Wiewiora [41] & Literature Review & Construction & & & $\checkmark$ & & & & & & & & & & & & & & & & & & & & & $\checkmark$ & & \\
\hline De Schepper, Dooms [186] & Comparative Case Study & Construction & & & $\checkmark$ & & & & & & & & & $\checkmark$ & & & & & & & & $\checkmark$ & $\checkmark$ & $\checkmark$ & & & & \\
\hline Shackleton, Hebinck [71] & Case Study & Construction & & & $\checkmark$ & & & & & & & & & $\checkmark$ & & & & & $\checkmark$ & $\checkmark$ & & & $\checkmark$ & $\checkmark$ & $\checkmark$ & $\checkmark$ & & $\checkmark$ \\
\hline Thomson, Austin [72] & Evaluative Study & Construction & $\checkmark$ & & $\checkmark$ & & & & & & & & $\checkmark$ & $\checkmark$ & & $\checkmark \checkmark \checkmark$ & & & & & & & $\checkmark$ & $\checkmark$ & & & & \\
\hline Himpe, Trappers [93] & Case Study & Construction & & & & & & & & & & & & & & & & & $\checkmark$ & & $\checkmark$ & & & & & $\checkmark$ & & $\checkmark$ \\
\hline $\begin{array}{l}\text { Hellströom, Ruuska [187] } \\
\text { Lu and Hao [111] }\end{array}$ & $\begin{array}{l}\text { Exploratory Case Study } \\
\text { Case Study }\end{array}$ & $\begin{array}{l}\text { Construction } \\
\text { Construction }\end{array}$ & & & & & & & & & & & & $\checkmark$ & & & & & & & & & & & & & $\checkmark$ & \\
\hline Im, Montoya [188] & Qualitative Survey Study & $\begin{array}{l}\text { New Product } \\
\text { Development }\end{array}$ & & & $\checkmark$ & & & & & & & & & $\checkmark$ & & $\checkmark$ & & & & & & $\checkmark$ & & $\checkmark$ & & & & \\
\hline Hsueh, Lee [80] & Evaluative Study & Construction & $\checkmark$ & & $\checkmark$ & & $\checkmark$ & & & & & & & & & & & & & & & & & & & & & \\
\hline
\end{tabular}


Table A2. Cont.

\begin{tabular}{|c|c|c|c|c|c|c|c|c|c|c|c|c|c|c|c|c|c|c|c|c|c|c|c|c|c|c|c|}
\hline Author & Methodology & Sector & $\bar{I}$ & Nㅗ & 85 & 茫点 & 占 & $\begin{array}{l}\text { 令 } \\
\end{array}$ & $\infty$ & 垔 & $\vec{E}$ & $\frac{2}{2}=$ & 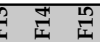 & 还 & 产 & $\stackrel{\infty}{\vec{I}}$ & एक & 产 & $\sqrt[3]{2}$ & तु & 蛋 & त्रे क्ष & $\vec{p}$ & d্ & Pु & $\stackrel{10}{2}$ & 兽 \\
\hline $\begin{array}{l}\text { Williams, Bouchlaghem [89] } \\
\text { Rezgui_Beach [112] }\end{array}$ & $\begin{array}{l}\text { Literature Review } \\
\text { Case Studv }\end{array}$ & $\begin{array}{l}\text { Construction } \\
\text { Construction }\end{array}$ & & & $\checkmark$ & & & & & & & & $\checkmark$ & $\checkmark$ & & & & & & $\checkmark$ & & & & & & & $\checkmark$ \\
\hline Lin [110] & Action Research & Construction & & & $\checkmark$ & & & & & & & & & & & & & & & & & & $\checkmark$ & & & & \\
\hline Shen, Zhang [109] & Case Study & Construction & & & & & & & $\checkmark$ & $\checkmark$ & & & & $\checkmark$ & & & & & $\checkmark$ & & & & & & $\checkmark$ & & \\
\hline Ghosh, Amaya [42] & Case Study & Construction & & & $\checkmark$ & & & & & & & & & $\checkmark$ & & & & & & & & & & & $\checkmark$ & & \\
\hline Belkadi, Dremont [189] & Evaluative Study & $\begin{array}{l}\text { Engineering } \\
\text { Design }\end{array}$ & & & $\checkmark$ & $\checkmark$ & & & & & & & & $\checkmark$ & & & & & & & & & & & $\checkmark$ & $\checkmark$ & \\
\hline Sanderson [190] & Literature Review & Construction & & & $\checkmark$ & & & & & & & & & & & & & & & & & $\checkmark$ & & & & & \\
\hline Liu, Hsueh [114] & Case Study & Construction & & & & & & & & & & & & & & & & & & & & & & & $\checkmark$ & & \\
\hline Tang, Shen [191] & Literature Review & Construction & & & $\checkmark$ & & & & & & & & & $\checkmark$ & $\checkmark$ & & & & & & & & & & & & \\
\hline Elf, Svedbo Engström [79] & Evaluative Study & Construction & & & & & & & & & $\checkmark$ & & & $\checkmark$ & $\checkmark$ & & & & & & & & & & & $\checkmark$ & \\
\hline Abduh, Soemardi [113] & Case Study & Construction & & & $\checkmark$ & & & & & & & & & & & & & & & & & & & & $\checkmark$ & & $\checkmark$ \\
\hline Chakraborty [73] & Case Study & Construction & & & $\checkmark$ & & & & & & & & & & & & & & & & & & & & & & \\
\hline Cavieres, Gentry [49] & Quantitative Model analysis & Construction & & & & & & & & & & $\checkmark$ & 6 & & & & & $\checkmark$ & & & & $\checkmark$ & & & & & \\
\hline Hopfe and Hensen [192] & Evaluative Study & Construction & & & & & & & & & & & & & & & & & & & & & & & & & \\
\hline Gasafi and Weil [115] & Case Study & Construction & & & & & & & & & & & & & $\checkmark$ & & & & & & & $\checkmark$ & & & & & \\
\hline $\begin{array}{l}\text { Jay and Bowen [66] } \\
\text { Yang Shen [193] }\end{array}$ & Qualitative Survey Study & $\begin{array}{l}\text { Construction } \\
\text { Construction }\end{array}$ & & $\checkmark$ & $s$ & & $\checkmark$ & & & & & $\checkmark$ & & 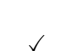 & & $\checkmark$ & & & & & $\checkmark$ & & & & & & \\
\hline Lin, Chang [75] & Evaluative Study & Construction & & & $\checkmark$ & & & & & & & & & $\checkmark$ & $\checkmark$ & & & & & & & $\checkmark$ & $\checkmark$ & & & & \\
\hline Leckner and Zmeureanu [194] & Evaluative Study & Construction & & & $\checkmark$ & & & & & & & & & & & & & & & & & & & & $\checkmark$ & & \\
\hline Chandra and Loosemore [116] & Case Study & Construction & & & & & & & & & & & & $\checkmark$ & & & & & & & & & & & & & \\
\hline Singh, Gu [117] & Case Study, Interviews & Construction & & & & & & & & & & $\checkmark$ & 6 & $\checkmark$ & & & & & & & & & & & & & \\
\hline Baalousha and Çelik [195] & Evaluative Study & Construction & $\checkmark$ & $\checkmark$ & $\checkmark$ & & & & & & & & & & & & & & & & & & & & & $\checkmark$ & \\
\hline Wolter and Meinel [94] & Evaluative Study & IT & & & $\checkmark$ & & & & & & & & & $\checkmark$ & & & & & & & & & & $\checkmark$ & & & \\
\hline Adeyeye, Bouchlaghem [90] & $\begin{array}{l}\text { Evaluative Study } \\
\text { Evive }\end{array}$ & Construction & & & & & & & & & & & & & & & & & & & & & & & & & \\
\hline Gu and London [196] & $\begin{array}{l}\text { Qualitative Evaluative } \\
\text { Research }\end{array}$ & Construction & & & & & & & & & & & & $\checkmark$ & & & & & & & & & & & & & \\
\hline Almeida, Sousa [197] & Evaluative Study & Construction & & & $\checkmark$ & & & $\checkmark$ & & & & & & $\checkmark$ & & & & & & & & & & $\checkmark$ & & & \\
\hline Razavi and Haas [198] & Evaluative Study & Construction & & & & & & & & & & & & & $\checkmark$ & & & & & & & & & & & & \\
\hline Luo, Shen [45] & Evaluative Study & Construction & & & $\checkmark$ & & & & $\checkmark$ & $\mathrm{v}$ & & & & $\checkmark$ & $\checkmark$ & $\checkmark$ & & & & & & & & $\checkmark$ & & & \\
\hline Chen, Okudan [82] & Literature Review & Construction & $\checkmark$ & & & & & & & & & $\checkmark$ & l & & & & $\checkmark$ & & & 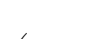 & & & & & 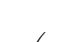 & 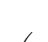 & \\
\hline $\begin{array}{l}\text { Romani, Lahoz [86] } \\
\text { van de Kar and Den Hengst [96]) }\end{array}$ & $\begin{array}{c}\text { Evaluative Study } \\
\text { Qualitative Survey Study }\end{array}$ & $\begin{array}{l}\text { IT } \\
\text { IT }\end{array}$ & & & & & & & & & & & & s & & & & & & $\checkmark$ & & & & & & $v$ & $\checkmark$ \\
\hline Chung, Kumaraswamy [199] & Literature Review & Construction & & & & & & & & & & & & $\checkmark$ & & & & & & & & & & & & & \\
\hline $\begin{array}{l}\text { Yeung, Chan [118] } \\
\text { (11) }\end{array}$ & $\begin{array}{l}\text { Case Study } \\
\text { Con }\end{array}$ & Construction & & & $\checkmark$ & & & & & & & & & $\checkmark$ & & & & & & & & & & & & & \\
\hline Elf and Malmqvist [51] & Evaluative Study & Construction & & & $\checkmark$ & & & & & & & & & $\checkmark$ & & & & & & & & & & & & & $\checkmark$ \\
\hline Jallow, Demian [43] & Qualitative Survey Study & Construction & & & $\checkmark$ & & & & & & & & & $\checkmark$ & & & & & & & & & & & & & \\
\hline Ross, Rhodes [200] & Evaluative Study & Construction & & & $\checkmark$ & & & & & & & & & & & & & & & & & & & & & & \\
\hline Yu, Shen [201] & Qualitative Survey Study & Construction & & & & & & & & & & & & $\checkmark$ & & & & & & & & & & & & & \\
\hline Baxter, Gao [12] & Case Study & Engineering & & & $\checkmark$ & & & & & & & & & & & & & & & & & & & & $\checkmark$ & & $\checkmark$ \\
\hline $\begin{array}{l}\text { Moodley, Smith [58] } \\
\text { George, Bell [29] }\end{array}$ & $\begin{array}{c}\text { Evaluative Study } \\
\text { Qualitative Survey Study }\end{array}$ & $\begin{array}{l}\text { Construction } \\
\text { Construction }\end{array}$ & & & $\checkmark$ & & $\checkmark$ & $\checkmark$ & $\checkmark$ & & & & & $\checkmark$ & & & & & & & & & & & $\checkmark$ & & $\checkmark$ \\
\hline Agouridas, McKay [202] & Case Study/Action research & $\begin{array}{l}\text { New Product } \\
\text { Development }\end{array}$ & & & $\checkmark$ & & & & & & & & & $\checkmark$ & & & & $\checkmark$ & & & & & & & & & \\
\hline
\end{tabular}




\section{References}

1. Tezel, A.; Koskela, L.; Aziz, Z. Current condition and future directions for lean construction in highways projects: A small and medium-sized enterprises (SMEs) perspective. Int. J. Proj. Manag. 2018, 36, $267-286$. [CrossRef]

2. Serugga, J.; Kagioglou, M.; Tzortzopoulos, P. A predictive method for benefits realisation through modelling uncertainty in front end design. In Proceedings of the 27th Annual Conference of the International Group for Lean Construction (IGLC), Dublin, Ireland, 3-5 July 2019.

3. Kagioglou, M.; Tzortzopoulos, P. Benefits realisation: An investigation of structure and agency. In Proceedings of the 24th Annual Conference of the International Group for Lean Construction, Boston, MA, USA, 20-22 July 2016; pp. 183-192.

4. Doherty, N.F. Re-Envisioning the Role of Benefits Realisation in A World Dominated by Robots; Institute of Electrical and Electronics Engineers (IEEE): Grenoble, France, 2016; pp. 1-6.

5. Bradley, G. Benefit Realisation Management: A Practical Guide to Achieving Benefits through Change; Routledge: New York, NY, USA, 2016.

6. Yates, K.; Sapountzis, S.; Lou, E.C.W.; Kagioglou, M. Bereal: Tools and Methods for Implementing Benefits Realisation and Management. In Proceedings of the 5th Nordic Conference on Construction Economics and Organisation, Reykjavík, Iceland, 10-12 June 2009.

7. Walters, L.E.M.; Scott, R.E.; Mars, M. Exploration of benefits realisation management for teledermatology scale-up framework development and sustainable scaling. Inform. Med. Unlocked 2019, 15, 100160. [CrossRef]

8. Dick, J.; Hull, E.; Jackson, K. Requirements Engineering; Springer: New York, NY, USA, 2017.

9. Laplante, P.A. Requirements Engineering for Software and Systems; Auerbach Publications: New York, NY, USA, 2017.

10. Bae, B.-Y.; Kim, S.; Lee, J.-W.; Van Nguyen, N.; Chung, B.-C. Process of establishing design requirements and selecting alternative configurations for conceptual design of a VLA. Chin. J. Aeronaut. 2017, 30, 738-751. [CrossRef]

11. Shieh, J.-I.; Wu, H.-H. Applying a hidden Markov chain model in quality function deployment to analyze dynamic customer requirements. Qual. Quant. 2008, 43, 635-644. [CrossRef]

12. Baxter, D.; Gao, J.; Case, K.; Harding, J.; Young, B.; Cochrane, S.; Dani, S. A framework to integrate design knowledge reuse and requirements management in engineering design. Robot. Comput. Manuf. 2008, 24, 585-593. [CrossRef]

13. Inayat, I.; Salim, S.S.; Marczak, S.; Daneva, M.; Shamshirband, S. A systematic literature review on agile requirements engineering practices and challenges. Comput. Hum. Behav. 2015, 51, 915-929. [CrossRef]

14. Burger, K.; White, L.; Yearworth, M. Understanding front-end project workshops with Social Practice Theory. Int. J. Proj. Manag. 2019, 37, 161-175. [CrossRef]

15. Elzomor, M.; Burke, R.D.; Parrish, K.; Gibson, G.E.; Gibson, G.E. Front-end planning for large and small infrastructure projects: Comparison of project definition rating index tools. J. Manag. Eng. 2018, 34, 04018022. [CrossRef]

16. Fuentes, M.; Smyth, H. Value co-creation at the front-end of project management: A service-dominant logic perspective. In Proceedings of the 32nd Annual ARCOM Conference; Chan, P., Neilson, C., Eds.; Association of Researchers in Construction Management: Manchester, UK, 2016.

17. Gibson, G.E., Jr.; Bingham, E.; Stogner, C.R. Front end planning for infrastructure projects. In Construction Research Congress 2010: Innovation for Reshaping Construction Practice; ASCE: Banff, AB, Canada, 2010; pp. 1125-1135.

18. Serugga, J.; Kagioglou, M.; Tzortzopoulos, P. Value generation in front-end design of social housing with qfd and multiattribute utility theory. J. Constr. Eng. Manag. 2020, 146, 04020019. [CrossRef]

19. Ost Scherer, J.; Kloeckner, A.P.; Ribeiro, J.L.D.; Pezzotta, G.; Pirola, F. Product-Service System (PSS) design: Using design thinking and business analytics to improve PSS design. Procedia CIRP 2016, 47, 341-346. [CrossRef]

20. Sinclair, D. RIBA Plan of Work 2013 Overview; Royal Institute of British Architects: London, UK, 2013.

21. Lawson, B. How Designers Think: The Design Process Demystified; Architectural Press: London, UK, 2005. 
22. Gibson, G.E., Jr.; Bosfield, R. Common barriers to effective front-end planning of capital projects. In Construction Research Congress 2012: Construction Challenges in a Flat World; ASCE: Denver, CO, USA, 2012; pp. 2459-2468. [CrossRef]

23. Macmillan, S.; Steele, J.; Austin, S.; Kirby, P.; Spence, R. Development and verification of a generic framework for conceptual design. Des. Stud. 2001, 22, 169-191. [CrossRef]

24. Blacud, N.A.; Bogus, S.M.; Diekmann, J.; Molenaar, K.R. Sensitivity of construction activities under design uncertainty. J. Constr. Eng. Manag. 2009, 135, 199-206. [CrossRef]

25. Codinhoto, R.; Koskela, L.; Tzortzopoulos, P.; Kagioglou, M. How analysis and synthesis have been understood in design. In Proceedings of the 14th Annual Conference of the International Group for Lean Construction, Santiago, Chile, 1 January 2006; pp. 121-134.

26. Laurian, L.; Walker, M.; Crawford, J. Implementing environmental sustainability in local government: The impacts of framing, agency culture, and structure in US cities and counties. Int. J. Public Adm. 2016, 40, 1-15. [CrossRef]

27. Harmon, D.J.; Haack, P.; Roulet, T.J. Microfoundations of institutions: A matter of structure versus agency or level of analysis? Acad. Manag. Rev. 2019, 44, 464-467. [CrossRef]

28. Almqvist, F. The fuzzy front-end and the forgotten back-end: User involvement in later development phases. Des. J. 2017, 20, S2524-S2533. [CrossRef]

29. George, R.; Bell, L.C.; Back, W.E. Critical activities in the front-end planning process. J. Manag. Eng. 2008, 24, 66-74. [CrossRef]

30. Gibson, G.E., Jr.; Irons, K.T.; Ray, M.P. Front end planning for buildings. In Building Integration Solutions; ASCE: Reston, VA, USA, 2006; pp. 1-14. [CrossRef]

31. Smyth, H.; Lecoeuvre, L.; Vaesken, P. Co-creation of value and the project context: Towards application on the case of Hinkley Point C Nuclear Power Station. Int. J. Proj. Manag. 2018, 36, 170-183. [CrossRef]

32. Oh, E.H.; Naderpajouh, N.; Hastak, M.; Gokhale, S. Integration of the construction knowledge and expertise in front-end planning. J. Constr. Eng. Manag. 2016, 142, 04015067. [CrossRef]

33. Halttula, H.; Haapasalo, H.; Aapaoja, A.; Manninen, S. Early involvement and integration in construction projects: The benefits of DfX in elimination of wastes. Int. J. Manag. Knowl. 2017, 6, 215-237.

34. Kukulies, J.; Schmitt, R. Stabilizing production ramp-up by modeling uncertainty for product design verification using Dempster-Shafer theory. CIRP J. Manuf. Sci. Technol. 2018, 23, 187-196. [CrossRef]

35. Jung, Y. Automated front-end planning for cost and schedule: Variables for theory and implementation. In AEI 2008: Building Integration Solutions; ASCE: Denver, Colorado, 2008; pp. 1-10.

36. Xiao, Y.; Watson, M. Guidance on conducting a systematic literature review. J. Plan. Educ. Res. 2017, 39, 93-112. [CrossRef]

37. Paré, G.; Trudel, M.-C.; Jaana, M.; Kitsiou, S. Synthesizing information systems knowledge: A typology of literature reviews. Inf. Manag. 2015, 52, 183-199. [CrossRef]

38. Reim, W.; Parida, V.; Örtqvist, D. Product-Service Systems (PSS) business models and tactics-A systematic literature review. J. Clean. Prod. 2015, 97, 61-75. [CrossRef]

39. Noordzij, M.; Hooft, L.; Dekker, F.W.; Zoccali, C.; Jager, K.J. Systematic reviews and meta-analyses: When they are useful and when to be careful. Kidney Int. 2009, 76, 1130-1136. [CrossRef] [PubMed]

40. Musawir, A.U.; Serra, C.E.M.; Zwikael, O.; Ali, I. Project governance, benefit management, and project success: Towards a framework for supporting organizational strategy implementation. Int. J. Proj. Manag. 2017, 35, 1658-1672. [CrossRef]

41. Pemsel, S.; Wiewiora, A.; Müller, R.; Aubry, M.; Brown, K. A conceptualization of knowledge governance in project-based organizations. Int. J. Proj. Manag. 2014, 32, 1411-1422. [CrossRef]

42. Ghosh, S.; Amaya, L.; Skibniewski, M.J. Identifying areas of knowledge governance for successful projects. J. Civ. Eng. Manag. 2012, 18, 495-504. [CrossRef]

43. Jallow, A.K.; Demian, P.; Baldwin, A.N.; Anumba, C.J. Lifecycle approach to requirements information management in construction projects: State-of-the-art and future trends. In Proceedings of the 24th Annual Conference of Association of Researchers in Construction Management ARCOM, University of Glamorgan, Cardiff, UK, 1-3 September 2008.

44. Office of Government Commerce. Managing Successful Projects with PRINCE2; The Stationery Office: London, UK, 2009. 
45. Luo, X.; Shen, Q.; Fan, S. A case-based reasoning system for using functional performance specification in the briefing of building projects. Autom. Constr. 2010, 19, 725-733. [CrossRef]

46. Samset, K.; Volden, G.H. Front-end definition of projects: Ten paradoxes and some reflections regarding project management and project governance. Int. J. Proj. Manag. 2016, 34, 297-313. [CrossRef]

47. Pegoraro, C.; de Paula, I.C. Requirements processing for building design: A systematic review. Production 2017, 27. [CrossRef]

48. Müller, A.; Ludwig, A.; Franczyk, B. Data security in decentralized cloud systems-system comparison, requirements analysis and organizational levels. J. Cloud Comput. 2017, 6, 15. [CrossRef]

49. Cavieres, A.; Gentry, T.R.; Al-Haddad, T. Knowledge-based parametric tools for concrete masonry walls: Conceptual design and preliminary structural analysis. Autom. Constr. 2011, 20, 716-728. [CrossRef]

50. Serugga, J.; Kagioglou, M.; Tzortzopoulos, P. Decision making: Value generation in front end design using quality function and utility theory. In Proceedings of the CIB World Building Congress 2019: Constructing Smart Cities, Hong Kong, China, 17-21 June 2019.

51. Elf, M.; Malmqvist, I. An audit of the content and quality in briefs for Swedish healthcare spaces. J. Facil. Manag. 2009, 7, 198-211. [CrossRef]

52. Locatelli, G.; Mancini, M.; Romano, E. Systems Engineering to improve the governance in complex project environments. Int. J. Proj. Manag. 2014, 32, 1395-1410. [CrossRef]

53. Mota, B.; Biotto, C.; Choudhury, A.; Abley, S.; Kagioglou, M. Lean design management in a major infrastructure project in UK. In Proceedings of the 27th Annual Conference of the International Group for Lean Construction (IGLC), Dublin, Ireland, 1-7 July 2019; pp. 37-48.

54. Fellows, R.; Liu, A. Sensemaking in the cross-cultural contexts of projects. Int. J. Proj. Manag. 2016, 34, 246-257. [CrossRef]

55. Drevland, F.O.; Tillmann, P.A. Value for whom? In Proceedings of the 26th Annual Conference of the International Group for Lean Construction, Chennai, India, 16-22 July 2018; pp. 261-270.

56. Mok, K.Y.; Shen, Q.; Yang, R. Addressing stakeholder complexity and major pitfalls in large cultural building projects. Int. J. Proj. Manag. 2017, 35, 463-478. [CrossRef]

57. Aragonés-Beltrán, P.; García-Melón, M.; Montesinos-Valera, J. How to assess stakeholders' influence in project management? A proposal based on the Analytic Network Process. Int. J. Proj. Manag. 2017, 35, 451-462. [CrossRef]

58. Moodley, K.; Smith, N.; Preece, C.N. Stakeholder matrix for ethical relationships in the construction industry. Constr. Manag. Econ. 2008, 26, 625-632. [CrossRef]

59. Becker, T.C.; Jaselskis, E.J.; El-Gafy, M. Improving predictability of construction project outcomes through intentional management of indirect construction costs. J. Constr. Eng. Manag. 2014, 140, 04014014. [CrossRef]

60. Leśniak, A.; Zima, K. Cost calculation of construction projects including sustainability factors using the Case Based Reasoning (CBR) method. Sustainability 2018, 10, 1608. [CrossRef]

61. Callegari, C.; Szklo, A.; Schaeffer, R. Cost overruns and delays in energy megaprojects: How big is big enough? Energy Policy 2018, 114, 211-220. [CrossRef]

62. Garcia-Ceballos, L.; de Andres-Díaz, J.R.; Contreras-Lopez, M.A. Life cycle study of different constructive solutions for building enclosures. Sci. Total Environ. 2018, 626, 1167-1174. [CrossRef] [PubMed]

63. Cavka, H.B.; Staub-French, S.; Poirier, E.A. Developing owner information requirements for BIM-enabled project delivery and asset management. Autom. Constr. 2017, 83, 169-183. [CrossRef]

64. Sousa-Zomer, T.; Cauchick-Miguel, P.A. Proposal of a hotspot-based approach to identifying social impacts along the product-service systems life cycle in the early design phases. Procedia CIRP 2017, 64, 85-90. [CrossRef]

65. Vezzoli, C.; Ceschin, F.; Diehl, J.C.; Kohtala, C. New design challenges to widely implement 'Sustainable Product-Service Systems'. J. Clean. Prod. 2015, 97, 1-12. [CrossRef]

66. Jay, I.; Bowen, P. What residents value in low-cost housing schemes: Some South African concepts. Build. Res. Inf. 2011, 39, 574-588. [CrossRef]

67. Locatelli, G.; Mariani, G.; Sainati, T.; Greco, M. Corruption in public projects and megaprojects: There is an elephant in the room! Int. J. Proj. Manag. 2017, 35, 252-268. [CrossRef]

68. Kyei, R.O.; Chan, A.P. Developing transport infrastructure in Sub-Saharan Africa through Public-Private Partnerships: Policy practice and implications. Transp. Rev. 2015, 36, 170-186. [CrossRef] 
69. Palm, J.; Reindl, K. Understanding energy efficiency in Swedish residential building renovation: A practice theory approach. Energy Res. Soc. Sci. 2016, 11, 247-255. [CrossRef]

70. Buyle, M.; Audenaert, A.; Braet, J.; Debacker, W. Towards a more sustainable building stock: Optimizing a Flemish dwelling using a life cycle approach. Buildings 2015, 5, 424-448. [CrossRef]

71. Shackleton, C.M.; Hebinck, P.; Kaoma, H.; Chishaleshale, M.; Chinyimba, A.; Shackleton, S.; Gambiza, J.; Gumbo, D. Low-cost housing developments in South Africa miss the opportunities for household level urban greening. Land Use Policy 2014, 36, 500-509. [CrossRef]

72. Thomson, D.; Austin, S.; Mills, G.R.; Devine-Wright, P. Practitioner understanding of value in the UK building sector. Eng. Constr. Arch. Manag. 2013, 20, 214-231. [CrossRef]

73. Chakraborty, S. Applications of the MOORA method for decision making in manufacturing environment. Int. J. Adv. Manuf. Technol. 2010, 54, 1155-1166. [CrossRef]

74. Senescu, R.R.; Haymaker, J.R.; Meža, S.; Fischer, M.A. Design process communication methodology: Improving the effectiveness and efficiency of collaboration, sharing, and understanding. J. Arch. Eng. 2014, 20, 05013001. [CrossRef]

75. Lin, L.-K.; Chang, C.-C.; Lin, Y.-C. Structure development and performance evaluation of construction knowledge management system. J. Civ. Eng. Manag. 2011, 17, 184-196. [CrossRef]

76. Thew, S.; Sutcliffe, A. Value-based requirements engineering: Method and experience. Requir. Eng. 2017, 23, 443-464. [CrossRef]

77. Vernet, N.; Coste, A. garden cities of the 21st century: A sustainable path to suburban reform. Urban Plan. 2017, 2, 45-60. [CrossRef]

78. Šurlan, N.; Cekic, Z.; Torbica, Z. Use of value management workshops and critical success factors in introducing local experience on the international construction projects. J. Civ. Eng. Manag. 2015, 22, 1021-1031. [CrossRef]

79. Elf, M.; Engström, M.; Wijk, H. An assessment of briefs used for designing healthcare environments: A survey in Sweden. Constr. Manag. Econ. 2012, 30, 835-844. [CrossRef]

80. Hsueh, S.-L.; Lee, J.-R.; Chen, Y.-L. DFAHP multicriteria risk assessment model for redeveloping derelict public buildings. Int. J. Strat. Prop. Manag. 2013, 17, 333-346. [CrossRef]

81. Malekitabar, H.; Ardeshir, A.; Sebt, M.H.; Stouffs, R. Construction safety risk drivers: A BIM approach. Saf. Sci. 2016, 82, 445-455. [CrossRef]

82. Chen, Y.; Okudan, G.E.; Riley, D.R. Sustainable performance criteria for construction method selection in concrete buildings. Autom. Constr. 2010, 19, 235-244. [CrossRef]

83. Pignataro, M.A.; Lobaccaro, G.; Zani, G. Digital and physical models for the validation of sustainable design strategies. Autom. Constr. 2014, 39, 1-14. [CrossRef]

84. Sousa-Zomer, T.; Cauchick-Miguel, P.A. A QFD-based approach to support sustainable product-service systems conceptual design. Int. J. Adv. Manuf. Technol. 2016, 88, 701-717. [CrossRef]

85. De Almeida, N.M.; Sousa, V.; Dias, L.A.; Branco, F. Engineering risk management in performance-based building environments. J. Civ. Eng. Manag. 2015, 21, 218-230. [CrossRef]

86. Romani, M.A.D.S.; Lahoz, C.H.N.; Yano, E.T. Identifying dependability requirements for space software systems. J. Aerosp. Technol. Manag. 2010, 2, 287-300. [CrossRef]

87. Rodrigues, C.; Freire, F. Building retrofit addressing occupancy: An integrated cost and environmental life-cycle analysis. Energy Build. 2017, 140, 388-398. [CrossRef]

88. Chiu, L.; Lowe, R.; Raslan, R.; Altamirano-Medina, H.; Wingfield, J. A socio-technical approach to post-occupancy evaluation: Interactive adaptability in domestic retrofit. Build. Res. Inf. 2014, 42, 574-590. [CrossRef]

89. Williams, T.; Bouchlaghem, D.; Loveday, D.; Law, C. Principal contractor involvement in post-occupancy evaluation in the UK construction industry. Facilities 2013, 31, 39-55. [CrossRef]

90. Adeyeye, K.; Bouchlaghem, D.; Pasquire, C. A conceptual framework for hybrid building projects. Facilities 2010, 28, 358-370. [CrossRef]

91. Wang, M.; Zhang, D.Q.; Su, J.; Dong, J.W.; Tan, S.K. Assessing hydrological effects and performance of low impact development practices based on future scenarios modeling. J. Clean. Prod. 2018, 179, 12-23. [CrossRef]

92. Russell-Smith, S.V.; Lepech, M.D. Cradle-to-gate sustainable target value design: Integrating life cycle assessment and construction management for buildings. J. Clean. Prod. 2015, 100, 107-115. [CrossRef] 
93. Himpe, E.; Trappers, L.; Debacker, W.; Delghust, M.; Laverge, J.; Janssens, A.; Moens, J.; Van Holm, M. Life cycle energy analysis of a zero-energy house. Build. Res. Inf. 2013, 41, 435-449. [CrossRef]

94. Wolter, C.; Meinel, C. An approach to capture authorisation requirements in business processes. Requir. Eng. 2010, 15, 359-373. [CrossRef]

95. Carrizo, D.; Dieste, O.; Juristo, N. Contextual attributes impacting the effectiveness of requirements elicitation Techniques: Mapping theoretical and empirical research. Inf. Softw. Technol. 2017, 92, 194-221. [CrossRef]

96. Van De Kar, E.; Hengst, M.D. Involving users early on in the design process: Closing the gap between mobile information services and their users. Electron. Mark. 2008, 19, 31-42. [CrossRef]

97. Knauss, E.; Yussuf, A.; Blincoe, K.; Damian, D.; Knauss, A. Continuous clarification and emergent requirements flows in open-commercial software ecosystems. Requir. Eng. 2016, 23, 97-117. [CrossRef]

98. Kruger, C.; Caiado, R.G.G.; França, S.L.B.; Quelhas, O.L.G. A holistic model integrating value co-creation methodologies towards the sustainable development. J. Clean. Prod. 2018, 191, 400-416. [CrossRef]

99. Serra, C.; Kunc, M. Benefits Realisation Management and its influence on project success and on the execution of business strategies. Int. J. Proj. Manag. 2015, 33, 53-66. [CrossRef]

100. Boton, C. Supporting constructability analysis meetings with Immersive Virtual Reality-based collaborative BIM 4D simulation. Autom. Constr. 2018, 96, 1-15. [CrossRef]

101. Śladowski, G. Use of meta-networks to evaluate key agents, knowledge and resources in the planning of construction projects. Arch. Civ. Eng. 2018, 64, 111-129. [CrossRef]

102. Hu, M. Dynamic life cycle assessment integrating value choice and temporal factors-A case study of an elementary school. Energy Build. 2018, 158, 1087-1096. [CrossRef]

103. Volk, R.; Luu, T.H.; Mueller-Roemer, J.S.; Sevilmis, N.; Schultmann, F. Deconstruction project planning of existing buildings based on automated acquisition and reconstruction of building information. Autom. Constr. 2018, 91, 226-245. [CrossRef]

104. Brioso, X.; Humero, A.; Murguia, D.; Corrales, J.; Aranda, J. Using post-occupancy evaluation of housing projects to generate value for municipal governments. Alex. Eng. J. 2018, 57, 885-896. [CrossRef]

105. Pal, S.K.; Takano, A.; Alanne, K.; Siren, K. A life cycle approach to optimizing carbon footprint and costs of a residential building. Build. Environ. 2017, 123, 146-162. [CrossRef]

106. Shen, W.; Tang, W.; Siripanan, A.; Lei, Z.; Duffield, C.; Wilson, D.; Hui, F.K.P.; Wei, Y. Critical success factors in Thailand's green building industry. J. Asian Arch. Build. Eng. 2017, 16, 317-324. [CrossRef]

107. Roux, C.; Schalbart, P.; Assoumou, E.; Peuportier, B. Integrating climate change and energy mix scenarios in LCA of buildings and districts. Appl. Energy 2016, 184, 619-629. [CrossRef]

108. Scholl, C.; Kemp, R. City labs as vehicles for innovation in urban planning processes. Urban Plan. 2016, 1, 89. [CrossRef]

109. Shen, W.; Zhang, X.; Shen, Q.; Fernando, T. The user pre-occupancy evaluation method in designer-client communication in early design stage: A case study. Autom. Constr. 2013, 32, 112-124. [CrossRef]

110. Lin, Y.-C. Construction network-based interface management system. Autom. Constr. 2013, 30, $228-241$. [CrossRef]

111. Lu, S.; Hao, G. The influence of owner power in fostering contractor cooperation: Evidence from China. Int. J. Proj. Manag. 2013, 31, 522-531. [CrossRef]

112. Rezgui, Y.; Beach, T.; Rana, O. A governance approach for BIM management across lifecycle and supply chains using mixed-modes of information delivery. J. Civ. Eng. Manag. 2013, 19, 239-258. [CrossRef]

113. Abduh, M.; Soemardi, B.W.; Wirahadikusumah, R.D. Indonesian construction supply chains cost structure and factors: A case study of two projects. J. Civ. Eng. Manag. 2012, 18, 209-216. [CrossRef]

114. Liu, K.-S.; Hsueh, S.-L.; Wu, W.-C.; Chen, Y.-L. A DFuzzy-DAHP decision-making model for evaluating energy-saving design strategies for residential buildings. Energies 2012, 5, 4462-4480. [CrossRef]

115. Gasafi, E.; Weil, M. Approach and application of life cycle screening in early phases of process design: Case study of supercritical water gasification. J. Clean. Prod. 2011, 19, 1590-1600. [CrossRef]

116. Chandra, V.; Loosemore, M. Communicating about organizational culture in the briefing process: Case study of a hospital project. Constr. Manag. Econ. 2011, 29, 223-231. [CrossRef]

117. Singh, V.; Gu, N.; Wang, X. A theoretical framework of a BIM-based multi-disciplinary collaboration platform. Autom. Constr. 2011, 20, 134-144. [CrossRef]

118. Yeung, J.F.; Chan, A.P.; Chan, D.W.M. A computerized model for measuring and benchmarking the partnering performance of construction projects. Autom. Constr. 2009, 18, 1099-1113. [CrossRef] 
119. Hwang, B.-G.; Shan, M.; Looi, K.-Y. Key constraints and mitigation strategies for prefabricated prefinished volumetric construction. J. Clean. Prod. 2018, 183, 183-193. [CrossRef]

120. Hujainah, F.; Abu Bakar, R.; Abdulgabber, M.A.; Zamli, K.Z. Software requirements prioritisation: A systematic literature review on significance, stakeholders, techniques and challenges. IEEE Access 2018, 6, 71497-71523. [CrossRef]

121. Jansson, G.; Viklund, E.; Olofsson, T. Artistic and engineering design of platform-based production systems: A study of Swedish architectural practice. Buildings 2018, 8, 34. [CrossRef]

122. Chesbrough, H.; Lettl, C.; Ritter, T. Value creation and value capture in open innovation. J. Prod. Innov. Manag. 2018, 35, 930-938. [CrossRef]

123. Chalhoub, J.; Ayer, S.K. Using Mixed Reality for electrical construction design communication. Autom. Constr. 2018, 86, 1-10. [CrossRef]

124. Sindhu, J.; Choi, K.; Lavy, S.; Rybkowski, Z.K.; Bigelow, B.F.; Li, W. Effects of front-end planning under fast-tracked project delivery systems for industrial projects. Int. J. Constr. Educ. Res. 2017, 14, 163-178. [CrossRef]

125. Du, J.; Wu, H.; Zhu, L. Influencing factors on profit distribution of Public-Private partnership projects: Private sector's perspective. Adv. Civ. Eng. 2018, 2018,1-10. [CrossRef]

126. Du, J.; Wu, H.; Zhao, X. Critical factors on the capital structure of Public-Private partnership projects: A sustainability perspective. Sustainability 2018, 10, 2066. [CrossRef]

127. Choi, J.; Leite, F.; Oliveira, D.P. BIM-based benchmarking system for healthcare projects: Feasibility study and functional requirements. Autom. Constr. 2018, 96, 262-279. [CrossRef]

128. Liao, P.-C.; Liao, J.-Q.; Wu, G.; Wu, C.; Zhang, X.; Ma, M.-C. Comparing international contractors' CSR communication patterns: A semantic analysis. J. Clean. Prod. 2018, 203, 353-366. [CrossRef]

129. Eleftheriadis, S.; Duffour, P.; Mumovic, D. Participatory decision-support model in the context of building structural design embedding BIM with QFD. Adv. Eng. Inform. 2018, 38, 695-711. [CrossRef]

130. Han, X.; Li, R.; Wang, J.; Qin, S.; Ding, G. Identification of key design characteristics for complex product adaptive design. Int. J. Adv. Manuf. Technol. 2017, 95, 1215-1231. [CrossRef]

131. Abeywickrama, D.B.; Ovaska, E. A survey of autonomic computing methods in digital service ecosystems. Serv. Oriented Comput. Appl. 2016, 11, 1-31. [CrossRef]

132. Goh, E.; Loosemore, M. The impacts of industrialization on construction subcontractors: A resource based view. Constr. Manag. Econ. 2016, 35, 288-304. [CrossRef]

133. Koh, E.C. A study on the requirements to support the accurate prediction of engineering change propagation. Syst. Eng. 2017, 20, 147-157. [CrossRef]

134. Papadonikolaki, E.; Verbraeck, A.; Wamelink, H. Formal and informal relations within BIM-enabled supply chain partnerships. Constr. Manag. Econ. 2017, 35, 531-552. [CrossRef]

135. Akcay, E.C.; Dikmen, I.; Birgonul, M.T.; Arditi, D. Estimating the profitability of hydropower investments with a case study from Turkey. J. Civ. Eng. Manag. 2017, 23, 1002-1012. [CrossRef]

136. Sinesilassie, E.G.; Tabish, S.Z.S.; Jha, K.N. Critical factors affecting schedule performance. Eng. Constr. Arch. Manag. 2017, 24, 757-773. [CrossRef]

137. Lin, H.; Zeng, S.; Ma, H.; Zeng, R.; Tam, V.W. An indicator system for evaluating megaproject social responsibility. Int. J. Proj. Manag. 2017, 35, 1415-1426. [CrossRef]

138. Sleiman, H.A.; Hempel, S.; Traversari, R.; Bruinenberg, S. An assisted workflow for the early design of nearly zero emission healthcare buildings. Energies 2017, 10, 993. [CrossRef]

139. Cardenas, I.; Voordijk, H.; Dewulf, G. Beyond theory: Towards a probabilistic causation model to support project governance in infrastructure projects. Int. J. Proj. Manag. 2017, 35, 432-450. [CrossRef]

140. Wiese, I.; Ré, R.; Wiese, I.; Kuroda, R.T.; Oliva, G.A.; Treude, C.; Gerosa, M. Using contextual information to predict co-changes. J. Syst. Softw. 2017, 128, 220-235. [CrossRef]

141. Hastie, J.; Sutrisna, M.; Egbu, C. Modelling knowledge integration process in early contractor involvement procurement at tender stage-A Western Australian case study. Constr. Innov. 2017, 17, 429-456. [CrossRef]

142. Sanderson, J.; Winch, G. Public policy and projects. Int. J. Proj. Manag. 2017, 35, 221-223. [CrossRef]

143. Samset, K. Systems engineering in front-end governance of major public investment projects. Systems 2017, 5, 13. [CrossRef]

144. Eckart, K.; McPhee, Z.; Bolisetti, T. Performance and implementation of low impact development-A review. Sci. Total. Environ. 2017, 607, 413-432. [CrossRef] [PubMed] 
145. Saoud, L.A.; Omran, J.; Hassan, B.; Vilutiene, T.; Kiaulakis, A. A method to predict change propagation within building information model. J. Civ. Eng. Manag. 2017, 23, 836-846. [CrossRef]

146. Clarke, L.; Gleeson, C.; Winch, C. What kind of expertise is needed for low energy construction? Constr. Manag. Econ. 2016, 35, 78-89. [CrossRef]

147. Oraee, M.; Hosseini, M.R.; Namini, S.B.; Merschbrock, C. Where the gaps lie: Ten years of research into collaboration on BIM-enabled construction projects. Constr. Econ. Build. 2017, 17, 121-139. [CrossRef]

148. Buchmann, R.A.; Karagiannis, D. Modelling mobile app requirements for semantic traceability. Requir. Eng. 2015, 22, 41-75. [CrossRef]

149. Shin, S.; Jeong, S.; Lee, J.; Hong, S.W.; Jung, S. Pre-Occupancy Evaluation based on user behavior prediction in $3 \mathrm{D}$ virtual simulation. Autom. Constr. 2017, 74, 55-65. [CrossRef]

150. Revellino, S.; Mouritsen, J. Knotting the net: From 'design by deception' to an object oriented politics. Int. J. Proj. Manag. 2017, 35, 296-306. [CrossRef]

151. Rowlinson, S. Building information modelling, integrated project delivery and all that. Constr. Innov. 2017, 17, 45-49. [CrossRef]

152. Heikkilä, V.T.; Paasivaara, M.; Lasssenius, C.; Damian, D.; Engblom, C. Managing the requirements flow from strategy to release in large-scale agile development: A case study at Ericsson. Empir. Softw. Eng. 2017, 22, 2892-2936. [CrossRef]

153. Galle, W.; De Temmerman, N.; De Meyer, R. Integrating scenarios into life cycle assessment: Understanding the value and financial feasibility of a demountable building. Buildings 2017, 7, 64. [CrossRef]

154. Dias, W.P.S.; Chandratilake, S.; Ofori, G. Dependencies among environmental performance indicators for buildings and their implications. Build. Environ. 2017, 123, 101-108. [CrossRef]

155. Kpamma, Z.; Adjei-Kumi, T.; Ayarkwa, J.; Adinyira, E. Participatory design, wicked problems, choosing by advantages. J. Eng. Constr. Arch. Manag. 2017, 24, 289-307. [CrossRef]

156. Hollberg, A.; Ruth, J. LCA in architectural design-A parametric approach. Int. J. Life Cycle Assess. 2016, 21, 943-960. [CrossRef]

157. Del Caño, A.; de la Cruz, M.P.; Gómez, D.; Pérez, M. Fuzzy method for analysing uncertainty in the sustainable design of concrete structures. J. Civ. Eng. Manag. 2016, 22, 924-935. [CrossRef]

158. Haddadi, A.; Johansen, A.; Andersen, B. A Conceptual framework to enhance value creation in construction projects. Procedia Comput. Sci. 2016, 100, 565-573. [CrossRef]

159. Davies, A.; Brady, T. Explicating the dynamics of project capabilities. Int. J. Proj. Manag. 2016, 34, $314-327$. [CrossRef]

160. Immonen, A.; Ovaska, E.; Kalaoja, J.; Pakkala, D. A service requirements engineering method for a digital service ecosystem. Serv. Oriented Comput. Appl. 2015, 10, 151-172. [CrossRef]

161. Nielsen, A.N.; Jensen, R.L.; Larsen, T.S.; Nissen, S.B. Early stage decision support for sustainable building renovation-A review. Build. Environ. 2016, 103, 165-181. [CrossRef]

162. Jussila, A.; Mainela, T.; Nätti, S. Formation of strategic networks under high uncertainty of a megaproject. J. Bus. Ind. Mark. 2016, 31, 575-586. [CrossRef]

163. Dave, B.; Kubler, S.; Främling, K.; Koskela, L. Opportunities for enhanced lean construction management using Internet of Things standards. Autom. Constr. 2016, 61, 86-97. [CrossRef]

164. Delmastro, C.; Mutani, G.; Corgnati, S.P. A supporting method for selecting cost-optimal energy retrofit policies for residential buildings at the urban scale. Energy Policy 2016, 99, 42-56. [CrossRef]

165. Addison, C.; Jenkins, B.W.C.; Odom, D.; Fortenberry, M.; Wilson, G.; Young, L.; Antoine-LaVigne, D. Building collaborative health promotion partnerships: The jackson heart study. Int. J. Environ. Res. Public Health 2015, 13, 25. [CrossRef] [PubMed]

166. Bacciotti, D.; Maccioni, L.; Cascini, G.; Rotini, F. Product planning techniques: Investigating the differences between research trajectories and industry expectations. Res. Eng. Des. 2016, 27, 367-389. [CrossRef]

167. Wei, H.-H.; Liu, M.; Skibniewski, M.J.; Balali, V. Conflict and consensus in stakeholder attitudes toward sustainable transport projects in China: An empirical investigation. Habitat Int. 2016, 53, 473-484. [CrossRef]

168. Ferreira, M.; Almeida, M.; Rodrigues, A. Cost-optimal energy efficiency levels are the first step in achieving cost effective renovation in residential buildings with a nearly-zero energy target. Energy Build. 2016, 133, 724-737. [CrossRef]

169. Müller, R.; Zhai, L.; Wang, A.; Shao, J. A framework for governance of projects: Governmentality, governance structure and projectification. Int. J. Proj. Manag. 2016, 34, 957-969. [CrossRef] 
170. Dias, R.; Cabral, A.S.; Lopez, B.; Belderrain, M.C.N. The use of cognitive maps for requirements elicitation in product development. J. Aerosp. Technol. Manag. 2016, 8, 178-192. [CrossRef]

171. Bayram, S.; Ocal, M.E.; Oral, E.L.; Atis, C. Comparison of multi layer perceptron (mlp) and radial basis function (rbf) for construction cost estimation: The case of Turkey. J. Civ. Eng. Manag. 2015, 22, 480-490. [CrossRef]

172. LeDoux, Y.; Teissandier, D.; Sebastian, P. Global optimisation of functional requirements and tolerance allocations based on designer preference modelling. J. Eng. Des. 2016, 27, 591-612. [CrossRef]

173. Hoła, B.; Sawicki, M.; Skibniewski, M.J. An IT model of a knowledge map which supports management in small and medium-sized companies using selected polish construction enterprises as an example. J. Civ. Eng. Manag. 2015, 21, 1014-1026. [CrossRef]

174. Plewa, C.; Sweeney, J.; Michayluk, D. Determining value in a complex service setting. J. Serv. Theory Pr. 2015, 25, 568-591. [CrossRef]

175. Lung, C.-H.; Balasubramaniam, B.; Selvarajah, K.; Elankeswaran, P.; Gopalasundaram, U. On building architecture-centric product line architecture. Requir. Eng. 2014, 20, 301-321. [CrossRef]

176. Dagan, D.; Isaac, S. Planning safe distances between workers on construction sites. Autom. Constr. 2015, 50, 64-71. [CrossRef]

177. Koh, E.C.; Förg, A.; Kreimeyer, M.; Lienkamp, M. Using engineering change forecast to prioritise component modularisation. Res. Eng. Des. 2015, 26, 337-353. [CrossRef]

178. Li, H.; Arditi, D.; Wang, Z. Determinants of transaction costs in construction projects. J. Civ. Eng. Manag. 2015, 21, 548-558. [CrossRef]

179. Singhaputtangkul, N.; Low, S.P. Modeling a decision support tool for buildable and sustainable building envelope designs. Buildings 2015, 5, 521-535. [CrossRef]

180. Jung, Y.; Moon, B.-S.; Kim, Y.-M.; Kim, W. Integrated cost and schedule control systems for nuclear power plant construction: Leveraging strategic advantages to owners and EPC firms. Sci. Technol. Nucl. Install. 2015, 2015, 1-13. [CrossRef]

181. Lu, Y.; Wang, S.; Shan, K. Design optimization and optimal control of grid-connected and standalone nearly/net zero energy buildings. Appl. Energy 2015, 155, 463-477. [CrossRef]

182. Too, E.; Weaver, P. The management of project management: A conceptual framework for project governance. Int. J. Proj. Manag. 2014, 32, 1382-1394. [CrossRef]

183. Tserng, H.-P.; Ho, S.-P.; Jan, S.-H. Developing bim-assisted as-built schedule management system for general contractors. J. Civ. Eng. Manag. 2014, 20, 47-58. [CrossRef]

184. Wong, K.K.W.; Kumaraswamy, M.; Mahesh, G.; Ling, F.Y.Y. Building integrated project and asset management teams for sustainable built infrastructure development. J. Facil. Manag. 2014, 12, 187-210. [CrossRef]

185. Shaikh, P.H.; Nor, N.B.M.; Nallagownden, P.; Elamvazuthi, I.; Ibrahim, T. A review on optimized control systems for building energy and comfort management of smart sustainable buildings. Renew. Sustain. Energy Rev. 2014, 34, 409-429. [CrossRef]

186. De Schepper, S.; Dooms, M.; Haezendonck, E. Stakeholder dynamics and responsibilities in Public-Private Partnerships: A mixed experience. Int. J. Proj. Manag. 2014, 32, 1210-1222. [CrossRef]

187. Hellström, M.; Ruuska, I.; Wikström, K.; Jåfs, D. Project governance and path creation in the early stages of Finnish nuclear power projects. Int. J. Proj. Manag. 2013, 31, 712-723. [CrossRef]

188. Im, S.; Montoya, M.M.; Workman, J.P. Antecedents and consequences of creativity in product innovation teams. J. Prod. Innov. Manag. 2012, 30, 170-185. [CrossRef]

189. Belkadi, F.; Dremont, N.; Notin, A.; Troussier, N.; Messadia, M. A meta-modelling framework for knowledge consistency in collaborative design. Annu. Rev. Control. 2012, 36, 346-358. [CrossRef]

190. Sanderson, J. Risk, uncertainty and governance in megaprojects: A critical discussion of alternative explanations. Int. J. Proj. Manag. 2012, 30, 432-443. [CrossRef]

191. Tang, L.; Shen, Q.; Skitmore, M.; Cheng, E.W.; Skitmore, M. Ranked critical factors in PPP briefings. J. Manag. Eng. 2013, 29, 164-171. [CrossRef]

192. Hopfe, C.J.; Hensen, J.L. Uncertainty analysis in building performance simulation for design support. Energy Build. 2011, 43, 2798-2805. [CrossRef]

193. Yang, R.; Shen, Q.; Ho, C.M.; Drew, D.S.; Xue, X. Stakeholder management in construction: An empirical study to address research gaps in previous studies. Int. J. Proj. Manag. 2011, 29, 900-910. [CrossRef] 
194. Leckner, M.; Zmeureanu, R. Life cycle cost and energy analysis of a Net Zero Energy House with solar combisystem. Appl. Energy 2011, 88, 232-241. [CrossRef]

195. Baalousha, Y.; Çelik, T. An integrated web-based data warehouse and artificial neural networks system for unit price analysis with inflation adjustment. J. Civ. Eng. Manag. 2011, 17, 157-167. [CrossRef]

196. Gu, N.; London, K. Understanding and facilitating BIM adoption in the AEC industry. Autom. Constr. 2010, 19, 988-999. [CrossRef]

197. De Almeida, N.M.; Sousa, V.; Dias, L.; Branco, F. A framework for combining risk-management and performance-based building approaches. Build. Res. Inf. 2010, 38, 157-174. [CrossRef]

198. Razavi, S.; Haas, C.T. Multisensor data fusion for on-site materials tracking in construction. Autom. Constr. 2010, 19, 1037-1046. [CrossRef]

199. Chung, J.K.; Kumaraswamy, M.; Palaneeswaran, E.; Chung, K.H.J. Improving megaproject briefing through enhanced collaboration with ICT. Autom. Constr. 2009, 18, 966-974. [CrossRef]

200. Ross, A.M.; Rhodes, D.H.; Hastings, D.E. Defining changeability: Reconciling flexibility, adaptability, scalability, modifiability, and robustness for maintaining system lifecycle value. Syst. Eng. 2008, 11, $246-262$. [CrossRef]

201. Yu, A.T.W.; Shen, Q.; Kelly, J.; Hunter, K. Comparative study of the variables in Construction Project Briefing/Architectural Programming. J. Constr. Eng. Manag. 2008, 134, 122-138. [CrossRef]

202. Agouridas, V.; McKay, A.; Winand, H.; De Pennington, A. Advanced product planning: A comprehensive process for systemic definition of new product requirements. Requir. Eng. 2007, 13, 19-48. [CrossRef]

(C) 2020 by the authors. Licensee MDPI, Basel, Switzerland. This article is an open access article distributed under the terms and conditions of the Creative Commons Attribution (CC BY) license (http://creativecommons.org/licenses/by/4.0/). 